\title{
Review \\ Rate and Timing of Application of Biostimulant Substances to Enhance Fruit Tree Tolerance toward Environmental Stresses and Fruit Quality
}

\author{
Carlo Andreotti ${ }^{1}(\mathbb{D})$, Youssef Rouphael ${ }^{2}(\mathbb{D})$, Giuseppe Colla ${ }^{3}(\mathbb{D})$ and Boris Basile ${ }^{2, *(D)}$ \\ 1 Faculty of Science and Technology, Free University of Bozen-Bolzano, 39100 Bolzano, Italy; \\ carlo.andreotti@unibz.it \\ 2 Department of Agricultural Sciences, University of Naples Federico II, 80055 Portici, Italy; \\ youssef.rouphael@unina.it \\ 3 Department of Agriculture and Forest Sciences, University of Tuscia, 01100 Viterbo, Italy; giucolla@unitus.it \\ * Correspondence: boris.basile@unina.it
}

check for

updates

Citation: Andreotti, C.; Rouphael, Y.; Colla, G.; Basile, B. Rate and Timing of Application of Biostimulant Substances to Enhance Fruit Tree Tolerance toward Environmental Stresses and Fruit Quality. Agronomy 2022, 12, 603. https://doi.org/ 10.3390 /agronomy 12030603

Academic Editor: Dionisios Gasparatos

Received: 25 January 2022

Accepted: 22 February 2022

Published: 28 February 2022

Publisher's Note: MDPI stays neutral with regard to jurisdictional claims in published maps and institutional affiliations.

Copyright: (C) 2022 by the authors. Licensee MDPI, Basel, Switzerland. This article is an open access article distributed under the terms and conditions of the Creative Commons Attribution (CC BY) license (https:// creativecommons.org/licenses/by/ $4.0 /)$.

\begin{abstract}
Biostimulants represent an important category of agricultural inputs characterized by multiple functions. They are used to assist crop growth, yield and to enhance the final quality of produces. Their classification is generally based on claims (i.e., which services they provide to the crop), even though their biological effects are often species-dependent and highly influenced by external factors (i.e., the growing conditions). This review provides a survey of the available scientific literature on the use of biostimulant substances in fruit production, with the specific aim to clarify their predominant mode and time of application. An extremely varied scenario emerged where foliar treatments are common for seaweed extracts, humic and fulvic acids, and where protein hydrolysates and silicon are applied both to the soil (drench) or sprayed to the canopy. Dosages were difficult to compare between the considered studies given the wide range of tested products and the uncertainty in their actual composition. Regarding the number of applications, biostimulants are generally applied following a calendar-approach, covering most of the growing season. When their use is intended to enhance crop tolerance toward environmental stresses, biostimulants are mainly applied before the stressful event to prime plant physiological defenses. Further studies based on multiple-year research projects and standard methodological protocols are urgently needed to verify a clear compliance with biostimulant claims and to evaluate their cost-effectiveness for the fruit production sector.
\end{abstract}

Keywords: dosage; time of application; seaweed; protein hydrolysate; silicon; fruit quality; abiotic stresses

\section{Introduction}

Because of the public concern about the use and/or abuse of chemical inputs (pesticides and fertilizers) in agriculture and the urgent call guided by government, authorities for more sustainable production systems [1] have significantly boosted the interest of the food industry for innovative and bio-based technologies able to decrease the environmental impact of the current production systems. Among new technologies, biostimulants have constantly increased their relevance in the last years and their economical relevance is expected to grow further in the future [2]. Biostimulants fit perfectly within the paradigm of the circular economy, often being the final products of processes of harvest, transformation and reuse of different natural-urban-industrial-agricultural waste materials [3]. After a period of fast and uncontrolled growth, at the European level, biostimulants have been recently defined based on their presumed effects on crop performances [4]. According to this claim-oriented definition, biostimulants are products able to improve one or more of the following plant or plant rhizosphere characteristics: (i) nutrient use efficiency; (ii) tolerance 
to abiotic stresses; (iii) quality traits; (iv) availability of confined nutrients in the soil or rhizosphere. Within this legal framework, biostimulants have been further classified into microbial (beneficial fungi and bacteria) and non-microbial (plant and seaweed extracts, biopolymers, protein hydrolysates, amino acids, humic acids, and minerals).

The availability on the market of a plethora of biostimulant products with different origin and putative functions might be taken as a good demonstration of their practical effectiveness and reliability as agronomic tools. Nevertheless, there is currently still a lack of precise and scientifically sound indications for the most effective mode of applications of biostimulants, even though their introduction in many integrated and organic production protocols for horticultural products has already become a praxis. This uncertainty is surely due to the actual nature of these products, whose composition often eludes the possibility for a detailed identification and quantification of all components with biological effect. Moreover, the composition of the same product category can change significantly depending on the type of raw material used as well as the conditions of the production process. A further consideration is that the biological effect induced by a biostimulant product can be ascribed to the combined effect of several molecules interacting together, rather than the cumulative result of the individual effect of each single molecule. If all these aspects are considered, including the interaction between the applied biostimulant and the plant genotype (specie, cultivar, clone) and/or the growing conditions (seasonal climatic variability), the final outcome is an extremely complex and somehow undetermined. From the methodology point of view, this complexity can be described as a sort of "methodological nightmare" [5], and possibly the reason for many inconclusive or incomplete researches on the topic.

This review aimed at providing practical information about the mode of application of different non-microbial biostimulant products. The literature research was decided to be restricted to selected biostimulant categories such as seaweed extracts, protein hydrolysates, humic, fulvic acids and inorganic compounds. As for the latter category, it consists of several beneficial elements, including aluminum, cobalt, sodium, selenium and silicon. In this review, the analysis was focused on Si alone since it is by far the most studied and relevant one, at least concerning fruit crops. The microbial biostimulants (i.e., the arbuscular mycorrhizal fungi and the plant growth promoting bacteria), because of their specificity in terms of mode of action (i.e., possible interaction with other microorganisms and the target crop) and application (dosages referring to spores number or colony forming unit), were not considered in this review. This approach allowed us to focus only on those products whose application methods are generally described following a certain standard of uniformity, therefore allowing interesting comparative evaluations between crops and growing conditions (protected or open field). The review is intentionally practically oriented, summarizing information in tables where, for each considered biostimulant category and purpose of application, the relevant aspects related to the mode of use (dosage, type of application, time, and number of applications) are provided and made available for an immediate and critical consideration. The review paper concludes by proposing some methodological criteria to follow for a claim-based evaluation of biostimulant effects and for the definition of the most efficient mode of use of these products. 


\section{Seaweed Extracts: Effects and Ways of Applications}

\subsection{Origin and Composition}

Seaweed extracts can be obtained from species belonging to different Phyla, such as Rhodophyta (red algae), Chlorophyta (green algae) and Phaeophyta (brown algae) [6]. Main components of algal extracts potentially expressing biostimulant effects are macro and micronutrients, polysaccharides, plant hormones, phenolic compounds, sterols and betaine [7]. The qualitative and quantitative composition of the extracts can be very different, being affected by the type of the seaweed species and by other important factors including the location and seasonal time of the harvest, and the extraction process. Any consideration related to dosages and ways of application of seaweed extracts should therefore carefully consider the actual composition of the selected products. Moreover, seaweed extracts can be applied to crops in different ways. Foliar sprays represent the predominant way of application, whereas application as soil amendment (by drenching or root dipping before planting) is generally restricted to specific aims related to the contrast of soil fatigue and/or soil borne diseases [8]. In both cases, the seaweed biostimulant actual absorption by the crop will depend also on environmental factors (temperature, air and soil humidity, radiations), which are able to affect the plant's general physiological status and consequently the possibility that the product's components will be taken up (through the stomatal openings or root absorption) by the plants. Despite green and red algae extracts being demonstrated to exert significant biostimulation activity when applied to different vegetable and horticultural crops [9-13], the literature on their application on fruit tree crops is very scarce. Finally, seaweed extracts can also be obtained from microalgae (i.e., Spirulina spp., Chlorella spp., Dunaliella spp. and others). The advantages in production of biostimulant products from microalgae are many (i.e., the high concentration of cells obtainable in photobioreactors, the uniformity and stability of the extract composition, the overall higher environmental sustainability of the growing processes), but unfortunately their targeted applications in crop science is still limited, especially with regard to fruit crop $[14,15]$.

\subsection{Seaweed Effects}

The effect of seaweeds applications on several crops has been widely investigated and extensive review works on this topic have been published in the last years [7,16-18]. Seaweed application has been shown to provide a range of services to crops. These include plant growth promotion (increased yield and/or biomass accumulation), increased quality of the harvested products (enhancement in the content of selected primary and secondary components of the quality) and higher tolerance toward stress, both abiotic (water and nutrient limitation, salinity) and biotic (antifungal and antibacterial properties) [6]. This experimental evidence has been obtained on different crops (annual species, ornamentals, vegetable and fruit crops), under different cultivation systems (open field, greenhouse). Here the aim is to provide a rational and organized view of the several aspects of seaweed application methods, listed within their areas of target actions on cropping systems. 


\subsection{Seaweed Application Methods to Increase Tolerance toward Drought}

Table 1 summarizes the main features of seaweed applications to contrast drought stress in horticultural crops. Most of the considered experimental works have been conducted under controlled or semi controlled conditions and with potted plants. Despite this evidence reflecting the need to create an artificial environment to induce controlled drought stress in plants, it also made clear the current gap of knowledge represented by the availability of scientific information on seaweed efficacy against water stress under open field conditions. When indications about the product typology were included in the methodology, brown algae were generally reported as the main raw material used for the obtainment of the seaweed extracts. Seaweed products were applied at concentrations ranging from 0.1 to $0.5 \%$, mainly as foliar sprays, often in combination with a low amount of wetting agents. In a couple of studies (on grapevine [19] and on sour orange [20]), foliar and drench ways of application were compared, with contrasting results. In grapevine, the foliar application fostered photosynthetic recovery after drought stress, whereas drench application did not provide any effect on vine physiological condition [19]. In sour orange, only the drench application increased stem water potential during water stress and the final biomass accumulation, whereas foliar application did not show a relevant effect on plant performances under water limitation [20]. Seaweed applications were generally repeated before and during the drought stress event, creating the conditions for a possible priming effect on the plant capacity to overcome the stressful condition. No studies were performed with the aim to investigate the curative potential of seaweed applications on a crop that already underwent a period of water limitation. Outcomes of the considered researches generally pointed out the capacity of treated plants to recover faster from a water stress condition than untreated plants, even though the physiological indicators selected in the study were not always able to depict significant differences in terms of growth and yield. Moreover, when seaweed products sharing the same origin were compared, different plant biochemical responses were induced in plants, therefore outlining the relevance of the actual product composition on the final expected results [21]. 
Table 1. Seaweed application methods to increase tolerance toward drought.

\begin{tabular}{|c|c|c|c|c|c|c|c|c|}
\hline $\begin{array}{c}\text { Seaweed } \\
\text { Description }\end{array}$ & Crop & $\begin{array}{l}\text { Growing } \\
\text { Conditions }\end{array}$ & $\begin{array}{l}\text { Application } \\
\text { Method }\end{array}$ & Dosage & Intervention Time & $\begin{array}{l}\text { Drought Stress } \\
\text { Application }\end{array}$ & $\begin{array}{l}\text { Effects on Crop } \\
\text { Performances }\end{array}$ & References \\
\hline $\begin{array}{l}\text { Seaweed origin } \\
\text { not defined }\end{array}$ & Grapevine & $\begin{array}{l}\text { Potted plants in } \\
\text { greenhouse }\end{array}$ & Foliar & $0.1 \%$ & $\begin{array}{c}2 \times \text { week for a } \\
\text { period of } 60 \text { days } \\
(16-17 \text { applications } \\
\text { in total })\end{array}$ & $\begin{array}{l}\text { One water regime } \\
\text { (irrigation was } \\
\text { withheld for } 6 \text { days } \\
\text { and then reapplied) }\end{array}$ & $\begin{array}{c}\text { Increased midday leaf } \\
\text { water potential, stomatal } \\
\text { conductance and leaf } \\
\text { net- } \mathrm{CO}_{2} \text { exchange rates. }\end{array}$ & [22] \\
\hline $\begin{array}{l}\text { A. nodosum } \\
\text { (alkaline } \\
\text { extraction) }\end{array}$ & Grapevine & $\begin{array}{l}\text { Potted vines in } \\
\text { greenhouse }\end{array}$ & Foliar or drench & $\begin{array}{c}1 \mathrm{~g} \mathrm{~L}^{-1}(0.1 \%)+ \\
\text { wetting agent }\end{array}$ & $\begin{array}{l}6 \text { applications in } \\
\text { total, } 5 \text { before the } \\
\text { stress and } 1 \text { at the } \\
\text { end of stress period } \\
\text { (priming and } \\
\text { recovery) }\end{array}$ & $\begin{array}{l}\text { One water regime } \\
\text { (Irrigation was } \\
\text { withheld for } 20 \text { days } \\
\text { and then reapplied) }\end{array}$ & $\begin{array}{l}\text { Foliar applications were } \\
\text { effective in fostering } \\
\text { photosynthetic rate after } \\
\text { recovery. Drench } \\
\text { applications did not affect } \\
\text { vine recovery }\end{array}$ & [19] \\
\hline $\begin{array}{l}\text { A. nodosum } \\
\text { (alkaline } \\
\text { extraction) }\end{array}$ & Grapevine & $\begin{array}{l}\text { Potted vines in } \\
\text { outdoor space }\end{array}$ & Foliar & $\begin{array}{c}1 \mathrm{~g} \mathrm{~L}^{-1}(0.1 \%)+ \\
\text { wetting agent }\end{array}$ & $\begin{array}{c}2 \text { applications, } \\
1 \text { week before the } \\
\text { stress event } \\
\text { (priming) }\end{array}$ & $\begin{array}{l}\text { One water regime } \\
\text { (irrigation was } \\
\text { withheld for } 5 \text { days } \\
\text { and then reapplied) }\end{array}$ & $\begin{array}{c}\text { Increased water } \\
\text { conductivity, lower leaf } \\
\text { temperature during stress, } \\
\text { faster recovery of } \\
\text { photosynthetic capacity }\end{array}$ & [23] \\
\hline $\begin{array}{c}\text { Seaweed } \\
\text { (undefined origin) } \\
\text { containing Alginic } \\
\text { acid 16\%) }\end{array}$ & Table grape & Open field & Foliar & $0.5 \%$ & $\begin{array}{l}2 \text { applications (at } \\
\text { millet-size and two } \\
\text { weeks later) }\end{array}$ & $\begin{array}{l}\text { Two water regimes: } \\
\text { well-watered (WW, } \\
\text { irrigation after } 60 \mathrm{~mm} \\
\text { evapotranspiration); } \\
\text { drought stress (DS, } \\
\text { irrigation after } \\
100 \mathrm{~mm} \text { ET, } \\
\text { evapotranspiration) }\end{array}$ & $\begin{array}{l}\text { Seaweed extract (SE) } \\
\text { increased the yield of DS } \\
\text { vines by }>80 \% \text { as } \\
\text { compared to DS control. } \\
\text { SE increased ABA, } \\
\text { proline, total phenol, and } \\
\text { soluble carbohydrates in } \\
\text { DS leaves }\end{array}$ & [24] \\
\hline $\begin{array}{l}\text { A. nodosum } \\
\text { (alkaline } \\
\text { extraction) }\end{array}$ & Orange & $\begin{array}{l}\text { Unshaded } \\
\text { greenhouse }\end{array}$ & $\begin{array}{l}\text { Foliar or drench } \\
\text { spray, once per } \\
\text { week }\end{array}$ & $5 \mathrm{~mL} \mathrm{~L}^{-1}(0.5 \%)$ & $\begin{array}{c}1 \times \text { week } \\
(12 \text { applications in } \\
\text { total })\end{array}$ & $\begin{array}{l}\text { Two irrigation } \\
\text { regimes }(100 \% \text { and } \\
50 \% \text { of ET) }\end{array}$ & $\begin{array}{l}\text { Increased vegetative } \\
\text { growth and water use } \\
\text { efficiency. }\end{array}$ & [25] \\
\hline $\begin{array}{l}\text { Seaweed origin } \\
\text { not defined }\end{array}$ & Strawberry & High tunnel & Foliar & $\begin{array}{c}1.33 \mathrm{~g} \mathrm{~L}^{-1} \\
(0.133 \%)\end{array}$ & $\begin{array}{l}4 \text { applications at } \\
20 \text { day interval over } \\
\text { a } 7 \text { months period } \\
\text { (1st application } \\
1 \text { month after } \\
\text { transplant) }\end{array}$ & $\begin{array}{c}\text { Four irrigation } \\
\text { regimes }(0.5,0.75,1.00 \\
\text { and } 1.25 \text { of ETc })\end{array}$ & $\begin{array}{l}\text { No indication on plant } \\
\text { physiological condition. } \\
\text { Improved fruit quality }\end{array}$ & [26] \\
\hline
\end{tabular}




\subsection{Increase Nutrient Uptake and Nutrient Use Efficiency}

Table 2 reports selected indications from the literature about the use of seaweed biostimulants to enhance nutrient uptake in horticultural crops. Once again, in the totality of the considered research papers, the experiments were conducted with plants cultivated in pot conditions. All studies used brown algae-derived products, the only exception being the green algae used by Mugnai et al. [27] on grapevine. When applied as foliar spray, the concentration ranged between 0.1 and $0.8 \%$ with multiple applications during the growth season. In only one experiment, a commercial seaweed extract was tested against an induced iron chlorosis [28]. In this case, a single drench application of brown seaweed extracts at high dosage ( $33 \%$ solution with tap water) was able to increase iron uptake with positive consequences on strawberry plants' growth, yield and physiological status. A similar study was also conducted on hydroponically cultivated tomato plants where iron chlorosis was induced by removing iron from the nutrient solution [29]. None of the four seaweed-based biostimulants (three from $A$. nodosum and one from $D$. potatorum) were effective in increasing Fe uptake, even though there were some modifications in the activation of the antioxidant systems (superoxide dismutase, catalase) in Fe-deficient plants. 
Table 2. Seaweed application methods to increase nutrient uptake and nutrient use efficiency.

\begin{tabular}{|c|c|c|c|c|c|c|}
\hline Seaweed Description & Crop & $\begin{array}{l}\text { Growing } \\
\text { Conditions }\end{array}$ & $\begin{array}{l}\text { Application Method } \\
\text { and Dosages }\end{array}$ & Intervention Time & $\begin{array}{c}\text { Effect on Nutrients Uptake and Crop Growth } \\
\text { Performances }\end{array}$ & References \\
\hline $\begin{array}{l}\text { Seaweed origin not } \\
\text { defined }\end{array}$ & Grapevine & $\begin{array}{l}\text { Potted plants in } \\
\text { greenhouse }\end{array}$ & Foliar, $0.1 \%$ & $\begin{array}{l}2 \times \text { week for a period of } \\
60 \text { days }(16-17 \\
\text { applications in total) }\end{array}$ & $\begin{array}{l}\text { Increased influx of } \mathrm{K}^{+} \text {and } \mathrm{Ca}^{2+} ; \text { increased } \\
\text { macronutrients accumulations in all plant organs. } \\
\text { Increased total biomass accumulation (dry weight) }\end{array}$ & [22] \\
\hline $\begin{array}{l}\text { Seaweed extracts from } \\
\text { brown and green algae }\end{array}$ & Grapevine & $\begin{array}{l}\text { Potted plants in } \\
\text { greenhouse }\end{array}$ & Drench, $0.1 \%$ & $\begin{array}{l}1 \times \text { week for a period of } \\
110 \text { days }(15-16 \\
\text { applications in total })\end{array}$ & $\begin{array}{l}\text { Brown algae increased plant growth and root } \\
\text { biomass; green algae were mostly effective in } \\
\text { increasing } \mathrm{NH}_{3}{ }^{+} \text {and } \mathrm{K}^{+} \text {absorption }\end{array}$ & [27] \\
\hline $\begin{array}{l}\text { Extracts from brown } \\
\text { seaweeds (Sargassu, } \\
\text { Laminaria, A. nodosum) }\end{array}$ & Strawberry & $\begin{array}{l}\text { Potted plants in open } \\
\text { conditions }\end{array}$ & $\begin{array}{c}\text { Drench by fertigation, } \\
0.2-0.8 \%\end{array}$ & $\begin{array}{l}\text { Two applications, at } \\
\text { flowering and } 20 \mathrm{~d} \text { later }\end{array}$ & $\begin{array}{l}\text { No effects on leaf macronutrients concentration. } \\
\text { Increased } \mathrm{Cu} \text { and } \mathrm{Zn} \text { at leaf level. No indication } \\
\text { about plant growth and yield }\end{array}$ & [31] \\
\hline $\begin{array}{c}\text { Seaweed extracts from } \\
\text { brown algae }\end{array}$ & Strawberry & $\begin{array}{l}\text { Potted plants in } \\
\text { greenhouse }\end{array}$ & $\begin{array}{l}\text { Drench, } 33.3 \%(10 \mathrm{~mL} \\
\text { of product in } 20 \mathrm{~mL} \\
\text { tap water) }\end{array}$ & $\begin{array}{c}\text { Once, } 1 \text { week after } \\
\text { lime-induced chlorosis }\end{array}$ & $\begin{array}{l}\text { Increased rhizosphere acidification with consequent } \\
\text { higher iron ions uptake. Increased vegetative } \\
\text { growth, leaf chlorophyll content, stomata density, } \\
\text { photosynthetic rate and yield. }\end{array}$ & [28] \\
\hline
\end{tabular}




\subsection{Seaweed Application Methods to Increase Yield and Product Quality}

Studies on the effect of seaweed extracts (all derived from brown algae, A. nodosum) on fruit quality were generally conducted in open field conditions, with few exceptions (Table 3). Seaweed-based biostimulants generally did not affect yield in fruit crops. Only on apple (cv Fuji), seaweed applications reduced the intensity of the alternate bearing in trees growing under a controlled nutrient deficiency [32]. Seaweed products were generally applied by foliar sprays at concentrations ranging from 0.15 to $0.7 \%$, often together with small amounts of wetting agent to increase the homogeneity of the product distribution over the plant canopy. Effects on primary fruit quality traits (e.g., sugar content and titratable acidity) were generally negligible, whereas seaweed extracts were often able to modulate the fruit phenolic profile, specifically increasing anthocyanins content and, consequently, fruit external coloration. This effect was confirmed in red grapevine cultivars (Sangiovese, Pinot noir, Cabernet sauvignon), independently from the area of cultivation and the seasonal meteorological conditions [33,34], on apple [35] and on strawberry [36]. Furthermore, brown algae applications were able to modulate the secondary metabolism of fruits, as indicated by the modified phenolic and aromatic profile of treated must and wine from a white grapevine cultivar (Tempranillo) [37-39]. Canopy sprays were often repeated during the growing season at a 1-2 week interval, generally covering the phenological phases from blooming to beginning of maturation (Table 3). In grapevine, applications were generally performed from pea-size berry stage until after veraison [33,34], whereas in other crops (i.e., strawberry), the first applications preceded blooming time [40] and subsequent sprays were performed up until one week before the first harvest. 
Table 3. Seaweed application methods to increase yield and product quality.

\begin{tabular}{|c|c|c|c|c|c|c|c|}
\hline Seaweed Description & Crop & $\begin{array}{l}\text { Growing } \\
\text { Conditions }\end{array}$ & $\begin{array}{l}\text { Application } \\
\text { Method }\end{array}$ & Dosage & Intervention Time & Effects on Crop Yield and Quality & References \\
\hline $\begin{array}{l}\text { Seaweed extracts } \\
\quad(\text { A. nodosum })\end{array}$ & Apple & Open field & Foliar & $0.27 \%\left(4 \mathrm{~kg} \mathrm{ha}^{-1}\right)$ & $\begin{array}{l}1 \times \text { week, from } 40 \text { days after } \\
\text { bloom until } 1 \text { week before } \\
\text { harvest (12 applications) }\end{array}$ & $\begin{array}{l}\text { No effect on yield. Increased fruit quality at harvest } \\
(+50 \%-+87 \% \text { of the fruits with more than } 75 \% \text { skin } \\
\text { overcoloration; }+220 \% \text { of total anthocyanin content in the skin) }\end{array}$ & [35] \\
\hline $\begin{array}{l}\text { Seaweed extracts } \\
\quad(\text { A. nodosum })\end{array}$ & Apple & Open field & Foliar & $\begin{array}{l}3.51 \text { and } 1.17 \mathrm{~L} \mathrm{ha}^{-1}(0.351 \text { and } \\
0.117 \% \text { if a total volume of } \\
\left.1000 \mathrm{~L} \mathrm{ha}^{-1} \text { was used }\right)\end{array}$ & $\begin{array}{l}7 \text { applications during the } \\
\text { growing season }\end{array}$ & $\begin{array}{l}\text { No effect on fruit yield. Sunburn incidence reduction } \\
\qquad(\sim-80 \%) \text { in treated fruits }\end{array}$ & [41] \\
\hline $\begin{array}{l}\text { Seaweed extracts } \\
\quad(\text { A. nodosum })\end{array}$ & Apple & Open field & $\begin{array}{l}\text { Drench by } \\
\text { fertigation }\end{array}$ & $\begin{array}{l}30 \mathrm{~L} \mathrm{ha}^{-1} \text { (total volume } \\
\text { unknown) }\end{array}$ & $\begin{array}{l}4 \text { applications during the } \\
\text { growing season }\end{array}$ & $\begin{array}{l}\text { Reduce alternate bearing in trees under sub-optimal } \\
\text { fertilization regime. Increased leaf chlorophyll content } \\
(\sim+12 \%) \text { and leaf photosynthetic performance }\end{array}$ & [32] \\
\hline $\begin{array}{l}\text { Seaweed extracts: (i) } \\
\text { A. nodosum plus K and } \\
\text { Zn; (ii) microalgae }\end{array}$ & Apple & Open field & Foliar & $\begin{array}{l}100 \mathrm{~mL} / 50 \mathrm{~L} \text { and } 200 \mathrm{~mL} / 50 \mathrm{~L} \\
(0.2 \% \text { and } 0.4 \% \text { in volume })\end{array}$ & 7 applications from fruit set & $\begin{array}{l}\text { Increased fruit nutritional quality. Microalgae enhanced } \\
\text { fruit redness (by 5-fold) and color index (by 8.5-fold) }\end{array}$ & [42] \\
\hline $\begin{array}{l}\text { Seaweed extracts } \\
\quad(\text { A. nodosum })\end{array}$ & Grapevine & Open field & Foliar & $\begin{array}{l}1.5 \text { and } 3 \mathrm{~kg} \mathrm{ha}^{-1} \text { (equivalent to } \\
\text { approximately } 0.15 \text { and } 0.3 \% \\
\text { concentration) with wetting agent }\end{array}$ & $\begin{array}{l}4 \text { applications at } 10-20 \text { day } \\
\text { interval, starting } 2 \text { weeks } \\
\text { before veraison }\end{array}$ & $\begin{array}{l}\text { No effect on yield. Increased anthocyanins and phenolic } \\
\text { compounds concentrations (both by } \sim+40 \% \text { ) }\end{array}$ & [33] \\
\hline $\begin{array}{l}\text { Seaweed extracts } \\
\quad(\text { A. nodosum })\end{array}$ & Grapevine & $\begin{array}{l}\text { Open field and } \\
\text { semi-controlled } \\
\text { conditions } \\
\text { (potted vines) }\end{array}$ & Foliar & $\begin{array}{l}\text { Open field: } 1.5 \mathrm{~kg} \mathrm{ha}^{-1} \\
\text { (equivalent to } 0.15 \% \\
\text { concentration); potted vines: } 3 \% \text {; } \\
\text { use of a wetting agent }\end{array}$ & $\begin{array}{l}\text { Open field: } 6 \text { applications at } \\
7-15 \text { day interval, starting } \\
\text { from pea-size stage; potted } \\
\text { vines: } 5 \text { applications during } \\
\text { the season }\end{array}$ & $\begin{array}{l}\text { No effect on yield and technological quality traits. } \\
\text { Increased anthocyanins }(\sim+10 \%) \text { and phenolic compounds } \\
(\sim+14.5 \%) \text { concentrations. Reduction in grey } \\
\text { mold incidence }\end{array}$ & [34] \\
\hline $\begin{array}{l}\text { Seaweed extracts } \\
\quad(\text { A. nodosum })\end{array}$ & Grapevine & Open field & Foliar & $\begin{array}{l}\text { Low dosage }\left(0.25 \% \mathrm{v} \mathrm{v}^{-1}\right) \text {; high } \\
\text { dosage }\left(0.5 \% \mathrm{v} \mathrm{v}^{-1}\right)\end{array}$ & $\begin{array}{l}\text { Two applications: the } 1 \text { st at } \\
\text { veraison, the } 2 \text { nd one } \\
\text { week after }\end{array}$ & $\begin{array}{l}\text { High dosages increased catechin }(\sim+48 \%) \text { and flavonols } \\
(\sim+37 \%) \text { concentration in berry and must; higher amino acids } \\
\text { concentration and yeast assimilable N in must and wine } \\
(\sim+35 \%) \text {; increased C6 aromatic compounds in wine }(\sim+6 \%)\end{array}$ & {$[37-39,43]$} \\
\hline $\begin{array}{l}\text { Seaweed extracts } \\
\text { (A. nodosum) combined } \\
\text { with silicon }\end{array}$ & Strawberry & $\begin{array}{c}\text { Semi- } \\
\text { controlled } \\
\text { conditions } \\
\text { (plastic tunnel) }\end{array}$ & Foliar & $\begin{array}{l}2 \mathrm{~mL} \mathrm{~L}^{-1}(0.2 \%) \text { in combination } \\
\text { with } \mathrm{SiO}_{2}\end{array}$ & $\begin{array}{l}4 \text { applications from } \\
\text { blooming to early fruit } \\
\text { development }\end{array}$ & $\begin{array}{l}\text { Increased early fruit maturation and yield }(\sim+12 \%) \text {. } \\
\text { Increased anthocyanins in first harvest }(\sim+30 \%) \text {. Reduction } \\
\text { in sugars }(-20 \%)\end{array}$ & [36] \\
\hline $\begin{array}{l}\text { Seaweed extracts } \\
\quad(\text { A. nodosum })\end{array}$ & Strawberry & Greenhouse & Foliar & $4 \mathrm{~g} \mathrm{~L}^{-1}(0.4 \%)$ & $\begin{array}{l}7 \text { applications at weekly } \\
\text { interval from pre-flowering } \\
\text { to fruit development stage }\end{array}$ & $\begin{array}{l}\text { No effect on total yield and primary quality traits. } \\
\text { Increased total phenolics content in fruits }(\sim+20 \%) \text {. }\end{array}$ & [40] \\
\hline $\begin{array}{l}\text { Seaweed extracts } \\
\quad(\text { A. nodosum })\end{array}$ & Olive & Open field & Foliar & $\begin{array}{l}0.5 \%\left(\mathrm{v} \mathrm{v}^{-1}\right) \text { in combination } \\
\text { with } \mathrm{N} \text { and B. Use of a } \\
\text { wetting agent }\end{array}$ & $\begin{array}{l}1 \text { application, } 10 \text { day after } \\
\text { full bloom }\end{array}$ & $\begin{array}{l}\text { Increased oil productivity }(\sim+30 \%) \text { and oil content in oleic } \\
(\sim+6.5 \%) \text { and linolenic acid }(\sim+18 \%) \text {; decrease in } \\
\text { palmitoleic, stearic and linoleic acid }(\sim-18 \div-25 \%)\end{array}$ & [44] \\
\hline $\begin{array}{l}\text { Seaweed extracts } \\
\quad(\text { A. nodosum })\end{array}$ & $\begin{array}{l}\text { Sweet } \\
\text { cherry }\end{array}$ & Open field & Foliar & $0.7 \%\left(\mathrm{v} \mathrm{v}^{-1}\right)$ & $\begin{array}{l}3 \text { applications }(6,4,2 \text { weeks } \\
\text { before harvest) }\end{array}$ & $\begin{array}{l}\text { No effect on yield and quality. Possible reduction in fruit } \\
\text { cracking }(-10 \% \text {, but no statistics applied) }\end{array}$ & [45] \\
\hline
\end{tabular}




\section{Silicon: Effects and Ways of Application}

\subsection{Origin and Composition}

Silicon (Si) in soil generally occurs in complexed forms like aluminum and crystalline silicates, reaching high concentration in mineral soil (up to around 28\%) [46]. These forms of $\mathrm{Si}$ are not available for plants that can absorb Si mainly as silicic acid, $\mathrm{Si}(\mathrm{OH})_{4}$. According to concentration in the plant tissues, Si can be considered as a macro $(>0.1 \%$ dry weight $)$ or a micronutrient $(<0.05 \%$ dry weight) depending on the crop species $[47,48]$. As a general indication, monocots (e.g., Poaceae) accumulate more Si than dicots. Among the latter, crop species belonging to Cucurbitaceae (e.g., cucumber), Fabaceae (e.g., pea), Rosaceae (e.g., elm), and Asteraceae (e.g., sunflower) have been found to be particularly rich in this element [49]. Soil desilication can occur because of the progressive Si removal with the harvest products. However, Si deficiency becomes rarely limiting for horticultural crops since these crops are not strong Si accumulators and because Si can be replenished with the irrigation, as water is also a source of silicon [50].

\subsection{Commercial Si-Containing Products}

Silicon-based products can be solid or liquid. Solid Si products are obtained from different sources (rocks, sediments, by-product from plants, recycled material) and therefore are characterized by very different Si content and properties (availability for the plant) depending on the characteristics of the raw material [51]. Silicon products can also be formulated as amorphous silica powder consisting of nanoparticles with sizes between 10 and $100 \mathrm{~nm}$. Liquid products contain Si in different formulations, such as mono or polysilicic acid. The Si concentration of liquid products corresponds to the Si content available for the plants. At high Si content, the product $\mathrm{pH}$ is high (around 9) and therefore dilution is required before product application [46]. Finally, silicon can be also formulated as colloidal gel of silicic acid.

\subsection{Silicon Effects and Mode of Application}

Beside the role as mineral nutrient for plants, silicon is also considered a biostimulant because of its capacity to interfere with different plant physiological processes, leading to increased plant growth, photosynthetic activity and tolerance toward environmental stressors [17]. These effects can be the consequence of mechanical or metabolic changes that occur in Si-treated plants. Mechanical changes are those typically induced by silica deposition (phytoliths formation) in the cell wall of epidermal cells [52]. Phytoliths increase cell wall thickness and mechanical strength with numerous positive consequences on leaf orientation (thereby photosynthetic capacity) and overall sturdiness against environmental threats (biotic or abiotic) [47]. Metabolic changes induced by Si applications are those responsible for the limitation of the oxidative damages caused by ROS (reactive oxygen species) in plants undergoing different stresses. Si has been found to be able to promote the antioxidant activity of selected enzymes (SOD, CAT, APX and others), therefore protecting plant cells from proteins, lipids, carbohydrates, and DNA degradation caused by ROS [53-55]. Beside protection from oxidative damage, Si can enhance water use efficiency under drought conditions by reducing cuticular and stomatal water losses due to transpiration [56].

Si-based products can be applied to the soil or by foliar sprays. Soil application is the most effective way to increase Si concentration in plant tissues. Si is absorbed as silicic acid at root level and, once entered in the xylem vessels, transported to shoots and leaves through the transpiration stream. At transpiration sites, Si accumulates as amorphous silica typically close to stomata openings, trichomes, lumens and intercellular voids [52]. Foliar application is less efficient in increasing Si concentration in plant tissues and generally requires high concentration of the sprayed solution (up to $1500 \mathrm{ppm}$ ) to be effective [46]. Nevertheless, the foliar application allows one to bypass problems related to possible $\mathrm{Si}$ immobilization in the soil and is therefore often chosen when repeated sprays of a target organ are needed. In this case, Si can be absorbed directly through the cuticle layer 
or through openings in the leaf surface (cracks close to trichomes, stomata, pores and hydathodes) [46].

\subsection{Silicon Application Methods to Increase Tolerance toward Drought and Salinity}

Table 4 reports the available experimental indications of the use of silicon to contrast drought or saline stress in fruit crops. The most common Si formulation tested in these experiments was potassium silicate $\left(\mathrm{K}_{2} \mathrm{SiO}_{3}\right)$, applied to the soil with the fertigation system [57] or, under greenhouse conditions, by pouring the Si-based solution directly inside the pot $[58,59] . \mathrm{K}_{2} \mathrm{SiO}_{3}$ was generally applied to the soil more than one time during the growing season with a Si concentration that ranged between 0.5 and $19.4 \mathrm{mM}$. However, a comparison between dosages was not always possible due to lack of clarity in the reported experimental methodology. Under different experimental conditions, $\mathrm{K}_{2} \mathrm{SiO}_{3}$-treated plants generally showed milder symptoms of water or salt stress, probably thanks to the higher metabolic antioxidant enzymatic activity against ROS molecules. Beside potassium silicate, other tested $\mathrm{Si}$ formulations were calcium metasilicate (Wollastonite, $\mathrm{CaSiO}_{3}$ ) and silicon nano particles. Foliar sprays with $\mathrm{Si}$ nanoparticles were performed at high concentrations (5.3 and $10.6 \mathrm{mM} \mathrm{Si}$ ) and were effective in partially overcoming the salt stress effects on mango trees [60]. 
Table 4. Silicon application methods to increase tolerance toward drought and salinity.

\begin{tabular}{|c|c|c|c|c|c|c|c|c|}
\hline Silicon Formulation & Crop & $\begin{array}{l}\text { Growing } \\
\text { Conditions }\end{array}$ & $\begin{array}{l}\text { Application } \\
\text { Method }\end{array}$ & Dosage & Intervention Time & $\begin{array}{c}\text { Drought or Salinity Stress } \\
\text { Application }\end{array}$ & Effects on Crop Performances & References \\
\hline $\begin{array}{l}\text { Potassium silicate } \\
\qquad\left(\mathrm{K}_{2} \mathrm{SiO}_{3}\right)\end{array}$ & Mango & Open field & Fertigation & $\begin{array}{c}1.5 \mathrm{mM} \mathrm{Si}^{-1} \\
\left(0.04 \mathrm{~g} \mathrm{~L}^{-1}\right)\end{array}$ & Every two weeks & $\begin{array}{l}\text { Drought stress: two water } \\
\text { regimes (water potential } \Psi \text { s: } \\
-0.18 \text { and }-0.77 \text { bars) }\end{array}$ & $\begin{array}{c}\text { Reduced ABA concentration and increased } \\
\text { antioxidative enzymes activity. Enhanced growth } \\
\text { and yield in treated trees. Increased tolerance to } \\
\text { water stressed conditions }\end{array}$ & [57] \\
\hline $\begin{array}{l}\text { Potassium silicate } \\
\left(\mathrm{K}_{2} \mathrm{SiO}_{3} \cdot 9 \mathrm{H}_{2} \mathrm{O}\right)\end{array}$ & Grapevine & $\begin{array}{l}\text { Potted plants } \\
\text { in greenhouse }\end{array}$ & Drench & $\begin{array}{c}2 \mathrm{mM} \text { of } \\
\mathrm{K}_{2} \mathrm{SiO}_{3} \cdot 9 \mathrm{H}_{2} \mathrm{O} \\
\left(0.3 \mathrm{~g} \mathrm{~L}^{-1}\right)\end{array}$ & Once & $\begin{array}{l}\text { Salinity stress: application up } \\
\text { to } 100 \mathrm{mM} \mathrm{NaCl}\end{array}$ & $\begin{array}{l}\text { Si mitigated the effect of the salinity stress by } \\
\text { increasing leaf photosynthesis and the maximum } \\
\text { yield and potential photochemical efficiency of the } \\
\text { photochemical reactions in photosystem II. }\end{array}$ & [58] \\
\hline $\begin{array}{l}\text { Wollastonite } \\
\left(\mathrm{CaSiO}_{3}\right)\end{array}$ & Apple & $\begin{array}{l}\text { Potted plants } \\
\text { in greenhouse }\end{array}$ & Drench & $\begin{array}{l}0.5,1 \text { and } 2 \mathrm{mM} \mathrm{Si} \\
(0.0014- \\
\left.0.028-0.05 \mathrm{~g} \mathrm{~L}^{-1}\right)\end{array}$ & $\begin{array}{l}\text { Twice per month } \\
\quad(4 \text { in total })\end{array}$ & $\begin{array}{c}\text { Salinity stress: } 0 \text { and } 35 \mathrm{mM} \\
\text { of } \mathrm{NaCl}\end{array}$ & $\begin{array}{l}\text { Increased stomatal conductivity, chlorophyll } \\
\text { concentration and biomass accumulation as } \\
\text { compared to salt stressed plants }\end{array}$ & [61] \\
\hline $\begin{array}{l}\text { Silicon nanoparticles } \\
\qquad(5-15 \mathrm{~nm})\end{array}$ & Mango & Open field & Foliar sprays & $\begin{array}{l}5.3 \text { and } 10.6 \mathrm{mM} \mathrm{Si} \\
(0.15 \text { and } \\
\left.0.30 \mathrm{~g} \mathrm{~L}^{-1}\right)\end{array}$ & $\begin{array}{l}\text { Two applications: } \\
\text { at full bloom and } 1 \\
\text { month after }\end{array}$ & $\begin{array}{l}\text { Salinity stress: use of } \\
\text { salinized drainage water } \\
\text { ( NaCl concentration } \\
\text { not reported) }\end{array}$ & $\begin{array}{l}\text { Increased leaf area, nutrients uptake, yield and } \\
\text { fruit quality in salt-stressed plants treated with } \\
\text { the nanoparticles }\end{array}$ & {$[60]$} \\
\hline $\begin{array}{l}\text { Potassium silicate } \\
\qquad\left(\mathrm{K}_{2} \mathrm{O}_{3} \mathrm{Si}\right)\end{array}$ & Strawberry & $\begin{array}{l}\text { Potted plants } \\
\text { in greenhouse }\end{array}$ & Drench & $\begin{array}{l}9.7 \text { and } 19.4 \mathrm{mM} \mathrm{Si} \\
\left(1 \text { and } 1.5 \mathrm{~g} \mathrm{~L}^{-1}\right)\end{array}$ & $\begin{array}{l}\text { One application } \\
\text { per week for two } \\
\text { months } \\
\text { (two seasons) }\end{array}$ & $\begin{array}{l}\text { Salinity stress: } 0 \text { and } 50 \mathrm{mM} \\
\mathrm{NaCl} \text {, added to } \\
\text { nutrient solution }\end{array}$ & $\begin{array}{l}\text { Increased peroxidase and superoxide dismutase } \\
\text { enzyme activity. Reduction of proline content. } \\
\text { Increased fruit yield in salt-stressed plants. }\end{array}$ & [59] \\
\hline
\end{tabular}


3.5. Silicon Application Methods to Contrast Nutrient Imbalances and to Increase Si Concentration in Plant Tissues

Table 5 summarizes methodological indications of the use of Si to overcome plant nutritional imbalances. Experiments on fruit crops were conducted in soilless conditions, with few exceptions. On strawberry, potassium silicate or silicic acid were applied at a concentration of 1.5-1.7 mM several times during the growing phases (from bud break to fruit development and maturation) $[62,63]$. Si applications by fertigation were found to be more effective than foliar sprays in promoting yield and fruit quality, even though Si was not efficient when used on Fe-deficient plants [62]. Under open field conditions, with soil cultivated crops (i.e., strawberry), improvement of the yield potential was not confirmed, highlighting the prevalence of the growing environment over the Si supply on yield parameters [63]. This evidence was also confirmed on blueberry, where growth performances were enhanced by $\mathrm{Si}$ applications in plants growing on a coconut fiber substrate but not on those plants growing on a sand [64]. Fertigation with silicic acid was also tested as a means to contrast soil acidification in a young apple orchard [65]. Si was unable to enhance soil $\mathrm{pH}$, but partially inhibited $\mathrm{Mn}$ and $\mathrm{Al}$ uptake with positive effects on tree health conditions and fruit yield [65].

\subsection{Silicon Application Methods to Increase Yield and Quality}

Table 6 lists relevant publications dealing with the effects of silicon applications on fruit crop yield and product quality. The formulations used were rather different (i.e., potassium silicate, metasilicate), and also included commercial products characterized by a complex mix of nutrients ( $\mathrm{Zn}, \mathrm{Fe}, \mathrm{Mn})$ in combination with Si $[35,36,40]$. The Si concentration in the tested formulations varied a lot in the different experimental conditions. Under open field conditions, drenching applications generally were performed at higher Si concentrations (178-280 mM Si) [66,67] as compared to foliar sprays $(0.05-98.2 \mathrm{mM} \mathrm{Si})[35,68]$. Under greenhouse conditions, with potted plants, Si was applied to the leaves or by fertigation at low concentrations, ranging from 0.08 to $0.5 \mathrm{mM} \mathrm{Si}[40,69]$. Independently from the application method, Si supply was repeated several times during the season, covering different growth stages of the considered crop. Overall, Si induced higher fruit firmness and, consequently, longer shelf life of perishable fruits (table grape and raspberry) [69,70]. Moreover, Si reduced the incidence of post-harvest disorder in stored fruits (on apple [35]). Finally, Si-treated plants were often more productive, independently from the growing conditions (open field or greenhouse) or the considered crops (strawberry, avocado, wine grape, table grape and raspberry) (Table 6). 
Table 5. Silicon application methods to contrast nutrient imbalances and to increase Si concentration in plant tissues.

\begin{tabular}{|c|c|c|c|c|c|c|c|c|}
\hline Silicon Formulation & Crop & $\begin{array}{l}\text { Growing } \\
\text { Conditions }\end{array}$ & $\begin{array}{l}\text { Application } \\
\text { Method }\end{array}$ & Dosage & Intervention Time & Nutrient Imbalances & Effects on Crop Performances & References \\
\hline Silicic acid $\left(\mathrm{H}_{4} \mathrm{SiO}_{4}\right)$ & Strawberry & $\begin{array}{l}\text { Soilless } \\
\text { cultivation } \\
\text { (with organic } \\
\text { substrate or } \\
\text { coconut fibers) }\end{array}$ & $\begin{array}{l}\text { Foliar or } \\
\text { fertigation }\end{array}$ & $\begin{array}{l}1.5 \mathrm{mM} \mathrm{Si}^{-1} \\
\left(0.04 \mathrm{~g} \mathrm{~L}^{-1}\right)\end{array}$ & $\begin{array}{l}\text { At visible } \\
\text { inflorescence, } \\
\text { flowering and fruit } \\
\text { development }\end{array}$ & $\begin{array}{c}\text { No Fe, Fe-deficiency and } \\
\text { Fe-sufficiency }\end{array}$ & $\begin{array}{l}\text { Drench application more effective than foliar. No Si } \\
\text { effects on Fe-deficient plants. Increased yield, fruit } \\
\text { quality and shelf life in Si-treated plants growing on } \\
\text { organic substrate }\end{array}$ & [62] \\
\hline $\begin{array}{l}\text { Liquid potassium } \\
\text { silicate }\left(\mathrm{K}_{2} \mathrm{O}_{3} \mathrm{Si}\right) \text { or } \\
\text { Wollastonite } \\
\left(\mathrm{CaSiO}_{3}\right)\end{array}$ & Strawberry & $\begin{array}{l}\text { Soilless or } \\
\text { open field } \\
\text { (soil) } \\
\text { cultivation }\end{array}$ & $\begin{array}{l}\text { Fertigation } \\
\text { and to the } \\
\text { soil at } \\
\text { plantation }\end{array}$ & $\begin{array}{l}1.7 \mathrm{mM}(0.047 \mathrm{~g} \\
\left.\mathrm{L}^{-1}\right) ; \mathrm{CaSiO}_{3}: 0,12, \\
24,36 \text { g plant }^{-1}\end{array}$ & $\begin{array}{l}\text { Constant, } \\
\text { bi-weekly }\left(\mathrm{K}_{2} \mathrm{O}_{3} \mathrm{Si}\right) \\
\text { or at plantation } \\
\left(\mathrm{CaSiO}_{3}\right)\end{array}$ & $\begin{array}{l}\text { None reported; different } \\
\text { growing media }\end{array}$ & $\begin{array}{l}\text { Under soilless conditions, Si increased yield fruit } \\
\text { marketability; no Si effect independently from dosages } \\
\text { and formulations under field conditions }\end{array}$ & [63] \\
\hline $\begin{array}{l}\text { Commercial product } \\
\text { (Siliforte) }\end{array}$ & Blueberry & $\begin{array}{l}\text { Soilless } \\
\text { cultivation }\end{array}$ & Fertigation & $\begin{array}{l}0,0.3,0.6,1.2 \mathrm{mM} \\
\mathrm{Si}\left(0-0.033 \mathrm{gL}^{-1}\right)\end{array}$ & $\begin{array}{l}\text { Fertigation started } \\
\text { when } 10 \% \text { of the } \\
\text { readily available } \\
\text { water was used }\end{array}$ & $\begin{array}{l}\text { Those related to the use } \\
\text { of two different } \\
\text { substrates (coconut fibers } \\
\text { vs. sand) }\end{array}$ & $\begin{array}{l}\text { Increase vegetative growth between } 8 \text { and } 25 \% \text { in } \\
\text { Si-treated plants growing in coconut fibers substrate. } \\
\text { No effects on those growing on sand }\end{array}$ & [64] \\
\hline Silicic acid $\left(\mathrm{H}_{4} \mathrm{SiO}_{4}\right)$ & Apple & Open field & Fertigation & $\begin{array}{c}0.21 \mathrm{mM} \\
(180-90-60 \mathrm{mg} \\
\left.\text { tree }^{-1}\right)\end{array}$ & $\begin{array}{l}\text { Fertigation started } \\
\text { mid May. Number } \\
\text { of Si applications: } \\
\qquad 12,6,4\end{array}$ & $\begin{array}{l}\text { Soil acidification below } \\
\text { irrigation drippers }\end{array}$ & $\begin{array}{l}\mathrm{Si} \text { applications (high rate) reduced trunk bark and leaf } \\
\text { concentration of Mn and } \mathrm{Al} \text {, whereas Si increased. } \\
\text { Si-treated trees (high dosage) increased growth and } \\
\text { yield, while reducing bark necrotic disorder }\end{array}$ & [65] \\
\hline
\end{tabular}


Table 6. Silicon application methods to increase yield and quality.

\begin{tabular}{|c|c|c|c|c|c|c|c|}
\hline Silicon Formulation & Crop & $\begin{array}{l}\text { Growing } \\
\text { Conditions }\end{array}$ & $\begin{array}{l}\text { Application } \\
\text { Method }\end{array}$ & Dosage & Intervention Time & Effects on Product Quality & References \\
\hline $\begin{array}{l}\text { Commercial product } \\
\left(\text { Siliforce }^{\circledR}\right) \text { containing } \\
\text { silicic acid }\left(\mathrm{H}_{4} \mathrm{SiO}_{4}\right) \text { in } \\
\text { combination with } \\
\text { other minerals }\end{array}$ & Apple & Open field & Foliar spray & $\begin{array}{l}0.05 \mathrm{mM} \mathrm{Si}\left(0.2 \mathrm{~mL} \mathrm{~L}^{-1}\right. \\
\left.\text { Siliforce }^{\circledR}\right)\end{array}$ & $\begin{array}{l}1 \times \text { week, from } 40 \text { day } \\
\text { after bloom until } 1 \text { week } \\
\text { before harvest } \\
\text { (12 applications) }\end{array}$ & $\begin{array}{l}\text { Depending on the season, Siliforce increased pulp } \\
\text { antioxidant potential (up to }+100 \% \text { ) and reduced } \\
\text { post-harvest disorders in stored apples }(\sim-10 \%)\end{array}$ & [35] \\
\hline $\begin{array}{l}\text { Commercial product } \\
\left(\mathrm{Siliforce}^{\circledR}\right) \text { containing } \\
\text { silicic acid }\left(\mathrm{H}_{4} \mathrm{SiO}_{4}\right) \text { in } \\
\text { combination with } \\
\text { other minerals }\end{array}$ & Strawberry & Greenhouse & Foliar sprays & $\begin{array}{c}0.08 \mathrm{mM} \mathrm{Si}\left(0.3 \mathrm{~mL} \mathrm{~L}^{-1}\right. \\
\left.\text { Siliforce }^{\circledR}\right)\end{array}$ & $\begin{array}{c}1 \times \text { week from } \\
\text { transplantation to fruit } \\
\text { maturation } \\
\text { (7 applications in total) }\end{array}$ & $\begin{array}{l}\text { Siliforce applications increased root biomass }(\sim+150 \%) \\
\text { and Si concentrations in roots and leaves. Si-treated } \\
\text { strawberry increased yield }(+20 \%) \text {; fruit showed lower } \\
\text { ascorbic acid content }(\sim-23 \%)\end{array}$ & [40] \\
\hline $\begin{array}{l}\text { Silicon dioxide } \\
\left(\mathrm{Optisyl}^{\circledR}, \mathrm{SiO}_{2}\right) \text { in } \\
\text { combination with } \\
\text { seaweed extracts }\end{array}$ & Strawberry & $\begin{array}{l}\text { Soil cultivation } \\
\text { system under } \\
\text { plastic tunnel }\end{array}$ & Foliar spray & $\begin{array}{l}0.669 \mathrm{mM}\left(0.2 \mathrm{~mL} \mathrm{~L}^{-1}\right. \\
\left.\text { Optisyl }^{\circledR}\right)\end{array}$ & $\begin{array}{l}4 \text { applications from } \\
\text { blooming to early fruit } \\
\text { development }\end{array}$ & $\begin{array}{l}\text { Increased yield and early maturation }(\sim+20 \%) \text {. } \\
\text { Increased coloration }(\sim+30 \% \text { anthocyanins } \\
\text { concentration). Reduction in sugars }(-20 \%)\end{array}$ & [36] \\
\hline $\begin{array}{l}\text { Potassium silicate ( } 32 \% \\
\left.\mathrm{SiO}_{2} \text { and } 21 \% \mathrm{~K}_{2} \mathrm{O}\right)\end{array}$ & Avocado & Open field & Drench & $\begin{array}{c}178 \mathrm{mM} \mathrm{Si} \\
(5000 \mathrm{ppm} \mathrm{Si})\end{array}$ & $\begin{array}{l}\text { Two-three times } \\
\text { per year }\end{array}$ & $\begin{array}{l}\text { Improved yield and fruit quality ( } 40 \% \text { increased } \\
\text { percentage of second grade fruits). No effect on tree } \\
\text { sanitary status }\end{array}$ & [66] \\
\hline $\begin{array}{l}\text { Potassium silicate (KSi, } \\
\qquad 28 \% \mathrm{Si})\end{array}$ & Sweet cherry & Open field & Drench & $\begin{array}{l}280 \mathrm{mM}(1 \% \text { soluble } \\
\text { potassium silicate })\end{array}$ & $\begin{array}{l}3 \text { applications, starting } \\
\text { from flowering at } \\
3 \text { weeks interval }\end{array}$ & $\begin{array}{l}\text { Increased fruit flesh firmness and stem pull force (both } \\
\text { around } 1 \% \text { ), without affecting sugar content }\end{array}$ & [67] \\
\hline $\begin{array}{l}\text { Sodium metasilicate } \\
\qquad\left(\mathrm{Na}_{2} \mathrm{SiO}_{3}\right)\end{array}$ & Grapevine & Open field & Foliar spray & $\begin{array}{l}0,32.7,65.5,98.2 \mathrm{mM} \mathrm{Si} \\
\left(0-12 \mathrm{~g} \mathrm{~L}^{-1} \mathrm{Na}_{2} \mathrm{SiO}_{3}\right)\end{array}$ & $\begin{array}{l}4 \text { applications to the } \\
\text { clusters (from pea size } \\
\text { to maturation) }\end{array}$ & $\begin{array}{l}\text { Increased yield per plant (up to }+130 \%) \text {; higher } \\
\text { phenolic content in clusters treated with } 4 \text { and } 8 \mathrm{~g} \mathrm{~L}^{-1} \\
\text { sodium metasilicate }(\sim+20 \%)\end{array}$ & [68] \\
\hline Silicate fertilizer & Table grape & Open field & Soil application & $600 \mathrm{~kg} \mathrm{ha}^{-1}\left(\mathrm{SiO}_{2}\right)$ & $\begin{array}{l}\text { Once to the plow layer } \\
\text { at blooming }\end{array}$ & $\begin{array}{l}\text { Increased yield components (cluster and berry weight, } \\
\text { total yield by } 13.5 \%) \text {, increased the soluble solids to } \\
\text { acidity ratio (around }+10 \%) \text {, reduced berry respiration } \\
\text { after harvest }(\sim-25 \%) \text {, prolonged shelf life }\end{array}$ & [70] \\
\hline $\begin{array}{l}\text { Potassium silicate } \\
\qquad\left(\mathrm{K}_{2} \mathrm{SiO}_{4}\right)\end{array}$ & Raspberry & $\begin{array}{l}\text { Greenhouse (potted } \\
\text { plants) }\end{array}$ & Fertigation & $\begin{array}{l}3 \mathrm{mM} \mathrm{K}_{2} \mathrm{SiO}_{4}(0.495 \\
\left.\mathrm{mM} \mathrm{Si}_{13} 13 \mathrm{mg} \mathrm{L}^{-1}\right)\end{array}$ & $\begin{array}{l}\text { Applied with the } \\
\text { nutrient solution for the } \\
\text { whole growing cycle }\end{array}$ & $\begin{array}{l}\text { Si-treated plants presented increased yield }(\sim+14 \%) \\
\text { higher fruit flesh firmness }(\sim+10 \%) \text { and shelf life }\end{array}$ & [69] \\
\hline
\end{tabular}




\section{Protein Hydrolysates: Effects and Ways of Application}

\subsection{Origin and Composition}

Protein hydrolysates (PHs) include a complex group of biostimulants that are defined as 'mixtures of polypeptides, oligopeptides and amino acids that are manufactured from protein sources using partial hydrolysis' [71]. They are generally classified based on the protein origin (animal or plant origin) and the production method (chemical or enzymatic hydrolysis) [72]. Both the origin and the hydrolysis method adopted strongly affect the specific composition of the PHs [72,73] and this aspect should be carefully taken into account when comparing the dosage and mode of application adopted for different formulates. In addition, PHs were reported to include also traces of other organic (lipids, carbohydrates, phenols, polyamines, etc.) and inorganic compounds (mineral elements) that may also partially contribute to their plant biostimulation activity [72-74]. The application of amino acids mixes or specific selected amino acids, which cannot be directly classified as protein hydrolysates, have also found interesting applications in different fruit tree crops (Tables 7 and 8). Protein hydrolysates (or single or mixed amino acids) are generally applied either as foliar sprays or as soil drench. The analysis of the literature appears to suggest that soil drench is the most common application method when the use of these biostimulants aims to increase tree/vine tolerance to abiotic stresses, whereas foliar sprays are more often adopted when the improvement of fruit yield and quality is desired. Few published studies compared different timings of application of this class of biostimulants, but there are clear evidences that their effectiveness of their foliar application in affecting berry composition at harvest strongly depends on the specific phenological stage when they are sprayed [75]. 
Table 7. Protein hydrolysate (PH) application methods to increase tolerance toward drought, salinity and thermal stress.

\begin{tabular}{|c|c|c|c|c|c|c|c|c|}
\hline PH Description & Crop & $\begin{array}{l}\text { Growing } \\
\text { Conditions }\end{array}$ & $\begin{array}{l}\text { Application } \\
\text { Method }\end{array}$ & Dosage & Intervention Time & $\begin{array}{l}\text { Drought Stress } \\
\text { Application }\end{array}$ & Effects on Crop Performances & References \\
\hline $\begin{array}{l}\mathrm{PH} \text { of unspecified } \\
\text { animal origin } \\
\text { neutralized with } \\
\text { Ca salts }\end{array}$ & Persimmon & Open field & Drench & $\begin{array}{l}0.143-0.715 \mathrm{~g} \mathrm{~L} \mathrm{~L}^{-1} \\
(0.0143-0.0715 \%)\end{array}$ & $\begin{array}{l}\text { Every } 6-8 \text { days in the } \\
\text { period July-August } \\
\text { ( } 7 \text { applications) or } \\
\text { May-September } \\
\text { (24 applications) }\end{array}$ & $\begin{array}{l}\text { Soil in } \\
\text { light-to-moderate } \\
\text { salinity conditions }\end{array}$ & $\begin{array}{l}\text { Decreased leaf chloride content, leaf necrosis, } \\
\text { and stem water potential }\end{array}$ & [76] \\
\hline $\begin{array}{l}\mathrm{PH} \text { of animal origin } \\
\text { (porcine red } \\
\text { blood cells) }\end{array}$ & Strawberry & $\begin{array}{l}\text { Field trial under } \\
\text { plastic tunnels }\end{array}$ & Drench & $2.5 \mathrm{~g} \mathrm{~L}^{-1}(0.25 \%)$ & $\begin{array}{l}\text { Every } 14-30 \text { days from } \\
\text { transplanting in the } \\
\text { period February-May } \\
\quad(5 \text { applications) }\end{array}$ & $\begin{array}{l}\text { Cold stress } \\
\text { conditions occurred } \\
\text { for five consecutive } \\
\text { nights after } \\
\text { transplanting }\end{array}$ & $\begin{array}{l}\text { Increased biomass of newly formed roots, early } \\
\text { flowering and production }\end{array}$ & [77] \\
\hline $\begin{array}{l}\mathrm{PH} \text { of animal origin } \\
\text { (porcine blood) }\end{array}$ & Strawberry & Open field & Drench & $0.5-1.5 \mathrm{~g} /$ plant & $\begin{array}{l}\text { Every } 7-16 \text { days in the } \\
\text { period April-May } \\
\text { ( } 4 \text { applications) }\end{array}$ & $\begin{array}{l}\text { Cold stress } \\
\text { conditions occurred } \\
\text { for three consecutive } \\
\text { nights during } \\
\text { growing season } \\
\text { (4-6 May) }\end{array}$ & Decreased percentage of damaged flowers & [78] \\
\hline $\begin{array}{l}\text { PH of plant origin } \\
\text { (soybean or lupin) or } \\
\text { animal origin (dairy } \\
\text { mix-based casein) }\end{array}$ & Grapevine & Open field & Foliar & $\begin{array}{l}1.6-6.4 \mathrm{~g} \mathrm{~L}^{-1} \\
(0.16-0.64 \%)\end{array}$ & $\begin{array}{l}\text { Every } 10 \text { days from } \\
\text { fruit set to bunch } \\
\text { closure ( } 3 \text { applications) }\end{array}$ & Hot and dry summer & $\begin{array}{c}\text { Decreased conductance index; increased leaf } \\
\text { temperature, yield and berry } \\
\text { anthocyanin content }\end{array}$ & [79] \\
\hline $\begin{array}{l}\text { PH of animal origin } \\
\text { (collagen-derived } \\
\text { protein) }\end{array}$ & Grapevine & $\begin{array}{l}\text { Potted vines in } \\
\text { outdoor space } \\
\text { under tunnel }\end{array}$ & Drench & $0.5 \mathrm{~g} \mathrm{~L}^{-1}(0.05 \%)$ & $\begin{array}{l}1 \text { application (at } \\
\text { "flowers separating" } \\
\text { stage), } 48 \text { days before } \\
\text { the water stress } \\
\text { application (priming) }\end{array}$ & $\begin{array}{l}\text { Two irrigation } \\
\text { regimes for } 18 \text { days } \\
\text { (100\% and } 30 \% \\
\text { field capacity) }\end{array}$ & $\begin{array}{l}\text { Increased leaf chlorophyll content (SPAD index), } \\
\text { young leaf growth, biomass in the aerial part } \\
\text { and berry diameter }\end{array}$ & [80] \\
\hline $\begin{array}{l}\text { PH of plant } \\
\text { origin (legumes) }\end{array}$ & Grapevine & $\begin{array}{l}\text { Potted vines in } \\
\text { outdoor space }\end{array}$ & Foliar & $3 \mathrm{~mL} \mathrm{~L}^{-1}$ & $\begin{array}{l}1 \text { application (two days } \\
\text { after the water } \\
\text { stress application) }\end{array}$ & $\begin{array}{l}\text { One water regime } \\
\text { (irrigation was } \\
\text { withheld in } \\
\text { pre-veraison for } \\
4 \text { days and then } \\
\text { reapplied) }\end{array}$ & $\begin{array}{l}\text { Up-regulation of photosynthesis-related } \\
\text { enzymes and of metabolites involved in plant } \\
\text { growth, nutrients uptake and brassinosteroids } \\
\text { biosynthesis; delay in technological } \\
\text { berry maturity }\end{array}$ & [81] \\
\hline Mix of amino acids & Grapevine & Open field & Foliar & $0.5 \%$ & $\begin{array}{l}2 \text { applications millet } \\
\text { sized berry and } \\
2 \text { weeks later) }\end{array}$ & $\begin{array}{l}\text { Two irrigation } \\
\text { regimes from April } \\
\text { to October (irrigation } \\
\text { applied after } 60 \text { or } \\
100 \text { mm evaporation } \\
\text { from pan } \\
\text { evaporation) }\end{array}$ & $\begin{array}{l}\text { Increased berry size, fruit yield, and berry total } \\
\text { soluble solids; decreased berry titratable acidity; } \\
\text { increased chlorophyll, ABA, proline, nutrients, } \\
\text { soluble carbohydrate and proteins; increased } \\
\text { ROS scavenging enzymes (GPX and CAT) }\end{array}$ & [24] \\
\hline
\end{tabular}


Table 8. Protein hydrolysate application methods to increase yield and product quality.

\begin{tabular}{|c|c|c|c|c|c|c|c|}
\hline $\begin{array}{c}\text { PH } \\
\text { Description }\end{array}$ & Crop & $\begin{array}{l}\text { Growing } \\
\text { Conditions }\end{array}$ & $\begin{array}{l}\text { Application } \\
\text { Method }\end{array}$ & Dosage & Intervention Time & Effects on Crop Yield and Quality & References \\
\hline $\begin{array}{l}\text { PH of plant origin } \\
\text { (alfalfa) or mix of amino } \\
\text { acid enriched with pure } \\
\text { phenylalanine }\end{array}$ & Apple & Open field & Foliar & $2 \mathrm{~g} \mathrm{~L}^{-1}(0.2 \%)$ & $\begin{array}{c}\text { Every week, from } \\
40 \text { days after bloom } \\
\text { until } 1 \text { week before } \\
\text { harvest } \\
\text { (12 applications) }\end{array}$ & Increased skin anthocyanin content $(+116 \%)$ & [35] \\
\hline $\begin{array}{l}\mathrm{PH} \text { of plant origin (mix } \\
\text { of corn, sorghum, } \\
\text { and carob) }\end{array}$ & Grapevine & Open field & $\begin{array}{l}\text { Drench by } \\
\text { fertigation }\end{array}$ & $\begin{array}{l}\text { It was applied in the } \\
\text { ratio of } 20 \mathrm{~L} \mathrm{ha}^{-1} \text { in } \\
\text { eight dosages, diluted } \\
\text { 1:500 in a water solution }\end{array}$ & 8 applications & $\begin{array}{l}\text { Increased must polyphenols }(+28 \%) \text { and anthocyanins } \\
\text { concentration }(+227 \%) ; \text { improved red color of the must (more } \\
\text { bluish-red colour); stimulated petunidin synthesis (not } \\
\text { detected in control). }\end{array}$ & [82] \\
\hline $\begin{array}{l}\text { PH of unspecified } \\
\text { origin }\end{array}$ & Apple & Open field & Foliar & $3 \mathrm{~g} \mathrm{~L}^{-1}(0.3 \%)$ & $\begin{array}{l}\text { Every 9-19 days from } \\
\text { when fruits of } 43 \mathrm{~mm} \\
\text { diameter } \\
\text { (7 applications) }\end{array}$ & $\begin{array}{l}\text { Increased fruit flesh total polyphenols }(+16 \%) \text { and antioxidant } \\
\text { activity of the skin at harvest }(\sim+20 \%) \text {; improved colorimetric } \\
\text { index of the skin after reddening }(\sim+80 \%)\end{array}$ & [42] \\
\hline $\begin{array}{c}\text { Amino acid } \\
\text { (phenylalanine) }\end{array}$ & Grapevine & Open field & Foliar & $\begin{array}{l}0.75 \mathrm{~g} \mathrm{~N} \mathrm{~L}-1 \\
(0.075 \%)\end{array}$ & $\begin{array}{l}2 \text { applications (veraison } \\
\text { and } 1 \text { week later) }\end{array}$ & $\begin{array}{c}\text { Increased total must amino acid concentration }(\sim+30 \%) \text { and } \\
\text { yeast assimilable nitrogen }(+58 \%)\end{array}$ & [83] \\
\hline $\begin{array}{c}\text { Amino acid } \\
\text { (phenylalanine) }\end{array}$ & Grapevine & Open field & Foliar & $\begin{array}{l}0.75 \mathrm{~g} \mathrm{~N} \mathrm{~L}^{-1} \\
(0.075 \%)\end{array}$ & $\begin{array}{l}2 \text { applications (veraison } \\
\text { and } 1 \text { week later) }\end{array}$ & $\begin{array}{l}\text { Increased total amino acid concentration in the must }(+227 \%) \\
\text { and increased concentration of stilbenes (trans-piceid; } \sim+50 \%) \\
\text { in the wine. }\end{array}$ & [84] \\
\hline $\begin{array}{c}\text { Amino acid } \\
\text { (phenylalanine) }\end{array}$ & Grapevine & $\begin{array}{l}\text { Open field and } \\
\text { potted vines in } \\
\text { greenhouse }\end{array}$ & Foliar & $\begin{array}{l}0.414-0.828 \mathrm{~g} \mathrm{~N} \mathrm{~L}^{-1} \\
\quad(0.041-0.083 \%)\end{array}$ & $\begin{array}{l}3 \text { applications (at } \\
16^{\circ} \text { Brix and } 2 \text { and } \\
5 \text { weeks later; the latter } \\
\text { corresponding to } \\
10 \text { days before harvest) }\end{array}$ & $\begin{array}{c}\text { Increased berry antioxidant activity }(\sim+5 \%-\sim+30 \%) \text { and } \\
\text { anthocyanin }(+20 \%-+101 \%) \text { and stilbene concentration } \\
(+34 \%-+132 \%) ; \text { activation of genes related to phenolic } \\
\text { synthesis pathway. }\end{array}$ & [86] \\
\hline $\begin{array}{c}\text { Amino acid } \\
\text { (phenylalanine) }\end{array}$ & Grapevine & Open field & Foliar & $\begin{array}{l}0.75-1.25 \mathrm{~g} \mathrm{~N} \mathrm{~L}^{-1} \\
(0.075-0.125 \%)\end{array}$ & $\begin{array}{l}2 \text { applications (veraison } \\
\text { and } 1 \text { week later) }\end{array}$ & $\begin{array}{l}\text { Increased synthesis of phenolic compound in berries }(+14 \% \text { in } \\
\text { total anthocyanins) }\end{array}$ & [87] \\
\hline $\begin{array}{c}\text { Amino acid } \\
\text { (phenylalanine) }\end{array}$ & Grapevine & Open field & Foliar & $\begin{array}{l}0.75-1.25 \mathrm{~g} \mathrm{~N} \mathrm{~L}^{-1} \\
(0.075-0.125 \%)\end{array}$ & $\begin{array}{l}2 \text { applications (veraison } \\
\text { and } 1 \text { week later) }\end{array}$ & $\begin{array}{l}\text { Increased content of several anthocyanins in the wine } \\
\qquad(+21 \%-+59 \%)\end{array}$ & [88] \\
\hline $\begin{array}{l}\text { Mix of amino acid of } \\
\text { plant origin and urea }\end{array}$ & Grapevine & Open field & Foliar & $\begin{array}{l}0.36-0.80 \mathrm{~g} \mathrm{~N} \mathrm{~L}^{-1} \\
(0.036-0.080 \%)\end{array}$ & $\begin{array}{l}\text { Every } 10 \text { days from full } \\
\text { veraison to harvest } \\
\text { (3- applications) }\end{array}$ & $\begin{array}{c}\text { Increased yeast assimilable nitrogen (YAN) concentration in } \\
\text { berries }(+89 \%-+163 \%)\end{array}$ & [75] \\
\hline $\begin{array}{l}\text { Amino acids } \\
\text { (tryptophan, glycine or } \\
\text { a mix of them) }\end{array}$ & Apple & Open field & Foliar & $\begin{array}{l}25-100 \mathrm{ppm} \\
(0.025-0.1 \%)\end{array}$ & $\begin{array}{l}3 \text { applications (before } \\
\text { bloom, full bloom, } \\
1 \text { month later) }\end{array}$ & $\begin{array}{c}\text { Increased leaf nutrient and chlorophyll concentrations; } \\
\text { Increased fruit set }(+9 \%-+24 \%) \text {, fruit size }(+14 \%-+21 \%) \text { and } \\
\text { fruit yield }(+75 \%-+162 \%) \text {; decreased fruit drop } \\
(-20 \%--31 \%) ; \text { increased fruit carbohydrate concentration } \\
(+7 \%-+46 \%) \text { and flesh firmness }(+18 \%-+79 \%)\end{array}$ & [89] \\
\hline
\end{tabular}




\subsection{Protein Hydrolysate Effects}

In the last decade, there has been a growing interest in studying the possible responses of several horticultural crops to protein hydrolysate application [72,73,90]. Scientific literature about fruit trees has highlighted that PHs can induce a wide range of potentially interesting effects that include (a) increasing tree tolerance of abiotic stresses (salinity, drought, and thermal stress), (b) positively affecting yield components (number of fruits and fruit size) and several compositional and physical traits directly related to fruit/berry quality at harvest (Tables 7 and 8). These studies were carried out by adopting either open-field trials or experiments under semi-controlled conditions (field experiments under plastic tunnels or trees/vines grown in containers).

\subsection{Protein Hydrolysate Application Methods to Increase Tolerance toward Abiotic Stresses}

Research on this topic focused mainly on three kinds of abiotic stresses-drought, cold and salinity (Table 7). Most of these studies were carried out on plants grown under field conditions (one under plastic tunnel), whereas two of them involved potted grapevines. In those studies aiming to test the suitability of PHs in improving the plant tolerance to salinity and cold stress, the biostimulants were applied only as drench, whereas in the trials on drought tolerance, PHs were applied either as drench or as foliar sprays. Most of the PHs adopted were of animal origin (Table 7), whereas in two cases they were either of plant origin [81] or they were described as a mix of amino acids of unknown origin [24]. PHs were applied at concentrations ranging between 0.01 and $0.64 \%$. The application of PHs was often repeated several times during the vegetative season, but in three of the studies they were applied only once [80,81] or twice [24]. As previously described for the seaweed extracts, $\mathrm{PH}$ application was often done before and then repeated during and/or after the occurrence of the abiotic stress and this suggests a possible priming action exerted by PHs toward low-temperature thermal stress [77,78] or other abiotic stresses [79]. This hypothesis is also supported by the results of two separate studies [80,81]; one foliar application of PHs applied before or right after (two days) the application of the water stress treatments mitigated the impact of this abiotic stress on the physiology and the vegetative/reproductive growth of grapevines.

\subsection{Protein Hydrolysate Application Methods to Improve Product Quality}

Most of these studies were carried out on trees/vines grown in open field conditions (only one of them was on potted grapevines grown in a greenhouse) (Table 8). Differently from when PHs were tested for increasing plant tolerance to abiotic stresses, most of the studies highlighting significant effects of PHs on fruit/berry composition applied these biostimulants as foliar sprays. Adopted PHs had either a plant or unspecified origin and they were applied at concentrations of $0.036-0.3 \%$ generally repeating the application several times during the growing season (at least two applications). The phenological stages when PHs were applied could cover the whole fruit development (in the case of apples) or be restricted specifically to fruit ripening (in the case of grapevines) (Table 8). As reported for seaweed application, the major effect of PHs on fruit composition involved a modulation of secondary metabolites such as polyphenols, anthocyanins, aroma precursors, and volatiles, that resulted in improved fruit skin coloration, antioxidant activity, and sensorial attributes $[35,42,82,85]$. Interestingly, foliar applications of amino acids induced an increase in grape berry yeast assimilable nitrogen (YAN) $[75,83]$. 


\section{Humic and Fulvic Acids: Effects and Ways of Application}

\subsection{Origin and Composition}

Humic and fulvic acids (HA and FA, respectively) are chemically complex humic substances derived from the chemical and biochemical transformation of plant and animal matter [91]. FAs are associations of small hydrophilic molecules that remain dispersed in solution independently of the $\mathrm{pH}$, whereas HAs are associations of prevalently hydrophobic molecules that are stabilized at neutral $\mathrm{pH}$ [92]. Being also naturally present in nature, the possible positive effects that these compounds can exert on plant physiology is well known, whereas their application in horticulture has been tested mainly in the last decade [91]. For the production of commercial formulations containing HAs and/or FAs, these compounds are extracted by different kinds of sources such as peat, lignites, composts, soil, and raw organic wastes [93].

\subsection{Humic and Fulvic Acids Effects and Mode of Application}

Humic and fulvic acids have being reported to induce in plants a range of potentially interesting physiological responses and these include growth stimulation, nutrient uptake enhancement, and stimulation of primary and secondary metabolism [91,93]. Despite the large potential applications that may be derived, only a limited amount of published research has focused on the study of the responses of fruit tree crops to the application of this important class of biostimulants (Table 9). Most of this research aimed at exploring the possible use of HAs and FAs to improve fruit yield and quality, whereas basically no studies directly investigated the effects of these biostimulants on fruit crops subjected to environmental stresses. The majority of the experiments on fruit trees and grapevines were carried out under open field conditions, whereas the strawberry trials considered potted plants grown in a greenhouse $[40,94]$. HAs and FAs, often of unknown origin, were generally applied as foliar sprays and in a few cases as soil drench [24,95] or a combination of these two application methods [95]. They were applied at concentrations ranging between 0.0025 and $1.5 \%$. In most experiments, HAs and FAs were applied 2-4 times during the vegetative season and these treatments generally started at pre-bloom or full bloom and were repeated during early fruit development stages. In most of the studies, the application of these biostimulants had a positive effect on fruit yield associated with an enhanced fruit/berry weight at harvest. Interestingly this effect was also reported in table grapes under water stress conditions [24]. The positive effect of these biostimulants on fruit yield was reported to be also related to an enhanced tree fertility in mango [96] and to an increased number of fruits per tree in pomegranate [97]. This response may be of large interest for alternate bearing fruit tree crops. Other chemical and physical attributes related to fruit quality were also reported to be affected positively by HA and FA application (Table 9). Among these, an increase in soluble solids content in fruit juice at harvest was often reported in several species such as grapevine [98], peach [95], mango [96], and pomegranate [97]. In addition, HAs and FAs can enhance the concentration of anthocyanins and vitamin $C$ with positive effects on fruit skin coloration and antioxidant capacity (Table 9). Most of these positive effects on primary and secondary metabolisms were also associated with improved plant nutritional status [40,94], leaf chlorophyll concentration [98], and photosynthetic activity $[40,98]$. Similar interesting responses were also reported in grapevines exposed to drought stress [24]. 
Table 9. Humic and fulvic acid (HA and FA respectively) application methods to increase yield and product quality.

\begin{tabular}{|c|c|c|c|c|c|c|c|}
\hline $\begin{array}{l}\text { HA and FA } \\
\text { Description }\end{array}$ & Crop & $\begin{array}{l}\text { Growing } \\
\text { Conditions }\end{array}$ & $\begin{array}{l}\text { Application } \\
\text { Method }\end{array}$ & Dosage & Intervention Time & Effects on Crop Yield and Quality & References \\
\hline $\begin{array}{l}\text { HAs and FAs from } \\
\text { vermicompost }\end{array}$ & Apricot & Open field & Foliar & $5 \mathrm{~g} \mathrm{~L}^{-1}(0.5 \%)$ & $\begin{array}{l}3 \text { applications (red ball, fruit setting } \\
\text { and fruit development) }\end{array}$ & $\begin{array}{l}\text { Increased antioxidant activity in fruits at harvest } \\
\qquad(\sim+60 \%-\sim+220 \%)\end{array}$ & [99] \\
\hline HAs of unknown origin & Peach & Open field & $\begin{array}{l}\text { Foliar } \\
\text { and/or } \\
\text { drench }\end{array}$ & $0.25-0.5 \%$ & $\begin{array}{l}4 \text { applications (every } 15 \text { days } \\
\text { starting after fruit set) }\end{array}$ & $\begin{array}{c}\text { Increased fruit weight }(+31 \%-+78 \%) \text {, fruit yield per tree } \\
(+31 \%-+78 \%) \text {, soluble solids content in fruit juice at harvest } \\
(+18 \%-+51 \%) \text {, skin anthocyanins }(+47 \%-+88 \%) \text {, and } \\
\text { decreased titratable acidity in fruit juice }(-19 \%--48 \%) \\
\text { at harvest }\end{array}$ & [95] \\
\hline HAs of unknown origin & Strawberry & $\begin{array}{l}\text { Potted plants } \\
\text { grown in } \\
\text { greenhouse }\end{array}$ & Foliar & $\begin{array}{c}0.025-0.100 \mathrm{~g} \\
\mathrm{~L}^{-1} \\
(0.0025-0.01 \%)\end{array}$ & $\begin{array}{l}2 \text { applications (full bloom and } 15 \\
\text { days later) }\end{array}$ & $\begin{array}{l}\text { Increased fruit weight }(+41 \%-+169 \%) \text {, fruit yield per plant } \\
(+55 \%-+116 \%) \text {, vitamin C content }(+1 \%-+2 \%) \text {, red color }\left(\mathrm{a}^{*} ;\right. \\
\quad+765 \%-+796 \%) \text {, leaf } \mathrm{P}, \mathrm{K}, \mathrm{Ca}, \mathrm{Mg} \text { concentration and } \\
\text { decreased total antioxidant capacity }(-8 \%--24 \%)\end{array}$ & [94] \\
\hline HAs of unknown origin & Strawberry & $\begin{array}{l}\text { Potted plants } \\
\text { grown in } \\
\text { greenhouse }\end{array}$ & Foliar & $1 \mathrm{~g} \mathrm{~L}^{-1}(0.1 \%)$ & $\begin{array}{l}7 \text { applications (every } 7 \text { days starting } \\
\text { from pre-bloom) }\end{array}$ & $\begin{array}{l}\text { Increased fruit Chroma value }(+41 \%) \text {, root } \mathrm{Si} \text { concentration, } \\
\text { leaf photosynthetic rate and decreased leaf area }\end{array}$ & [40] \\
\hline HAs of unknown origin & Pomegranate & Open field & Foliar & $0.5-1.5 \%$ & $\begin{array}{l}2 \text { applications (two and eight weeks } \\
\text { after full bloom) }\end{array}$ & $\begin{array}{l}\text { Increased fruit yield per tree }(+18 \%-+64 \%) \text {, fruit weight } \\
(+13 \%-+50 \%), \text { number of fruits per tree }(+8 \%-+39 \%), \\
\text { percent of fruit juice }(+5 \%-+10 \%) \text {, soluble solids content of } \\
\text { fruit juice }(+14 \%-+19 \%) \text { at harvest, and decreased titratable } \\
\text { acidity of fruit juice at harvest }(-8 \%--19 \%)\end{array}$ & [97] \\
\hline
\end{tabular}




\section{Final Remarks}

The main goal of the present review was to shed some light on the different mode of use of non-microbial biostimulants in fruit crops. After the analysis of the available literature, an extremely varied scenario emerged, characterized by a wide range of methods, dosages, times, and number of applications. Foliar sprays were predominant for seaweed extracts and, surprisingly, for humic and fulvic acids. Both foliar and drench (or soil) applications were common for protein hydrolysates and silicon, depending on the purpose of the treatment (to increase yield/fruit quality or to enhance tolerance toward abiotic stresses, respectively). In all cases, applications were performed several times during the considered period to sustain plant growth and productivity throughout the whole growing season. With regards to the use of biostimulants against environmental stresses, treatments generally were done before and during the rise of the stressful conditions, as a way to bust the natural plant defenses, predominantly following a preventive approach. Overall, greater consideration should be given to the actual uptake process that follows the biostimulant application. Increasing the knowledge of the factors (environmental, technological) affecting the product's capacity to be absorbed by the target organs (leaves, fruits, roots) would allow an higher efficacy of the biostimulant treatments with positive consequences especially on their economic sustainability. Another aspect that should be outlined are the different methodologies through which the product claims are generally tested. In this respect standard methodologies and protocols for multiple-year experiments are lacking, leading to very difficult comparisons between research outcomes. This is particularly valid for perennial crops (as fruit trees), where the impact of the previous seasons environmental and growing conditions might be present (i.e., carry-over effect), potentially hindering the actual functionality and effectiveness of the biostimulant products. To deal with this issue (i.e., the availability of common protocols to standardize the evaluation of commercial biostimulants), the European Committee for Standardization has recently established a technical committee (Technical Committee CEN/TC 455 on Plant Biostimulants) that will set common rules for the products' conformity assessment, including the authorization to the use of the CE mark.

Author Contributions: Conceptualization, C.A., Y.R., G.C. and B.B.; writing-original draft preparation, C.A. and B.B.; writing-review and editing, C.A., Y.R., G.C. and B.B. All authors have read and agreed to the published version of the manuscript.

Funding: This research received no external funding.

Institutional Review Board Statement: Not applicable.

Informed Consent Statement: Not applicable.

Data Availability Statement: Not applicable.

Conflicts of Interest: The authors declare no conflict of interest.

\section{References}

1. UN. Sustainable Development Goals. Available online: https://www.un.org/sustainabledevelopment/ (accessed on 24 January 2022).

2. Transparency Market Research. Biostimulants Market Insights, 2021-2031. Available online: https://www.transparencymarke tresearch.com/biostimulants-market.html (accessed on 24 January 2022).

3. Du Jardin, P. Plant biostimulants: A new paradigm for the sustainable intensification of crops. In Biostimulants for Sustainable Crop Production; Rouphael, Y., du Jardin, P., Brown, P., De Pascale, S., Colla, G., Eds.; Burleigh Dodds Science Publishing Limited: Cambridge, UK, 2020; pp. 3-29.

4. EU. Regulation of the European Parliament and of the Council Laying Down Rules on the Making Available on the Market of EU. Fertilising Products and Amending Regulations. (EC) No 1069/2009 and (EC) No 1107/2009 and Repealing Regulation (EC) No 2003/2003. Available online: https:/ / eur-lex.europa.eu/legal-content/EN/TXT/?uri=OJ:L:2019:170:TOC (accessed on 24 January 2022).

5. Andreotti, C. Management of abiotic stress in horticultural crops: Spotlight on biostimulants. Agronomy 2020, 10, 1514. [CrossRef]

6. Michalak, I.; Tyśkiewicz, K.; Konkol, M.; Rój, E.; Chojnacka, K. Seaweed extracts as plant biostimulants in agriculture. In Biostimulants for Sustainable Crop Production; Rouphael, Y., du Jardin, P., Brown, P., De Pascale, S., Colla, G., Eds.; Burleigh Dodds Science Publishing Limited: Cambridge, UK, 2020; pp. 77-124. 
7. Battacharyya, D.; Babgohari, M.Z.; Rathor, P.; Prithiviraj, B. Seaweed extracts as biostimulants in horticulture. Sci. Hortic. 2015, 196, 39-48. [CrossRef]

8. Sultana, V.; Ara, J.; Ehteshamul-Haque, S. Suppression of root rotting fungi and root knot nematode of chili by seaweed and Pseudomonas aeruginosa. J. Phytopathol. 2008, 156, 390-395. [CrossRef]

9. Ashour, M.; El-Shafei, A.A.; Khairy, H.M.; Abd-Elkader, D.Y.; Mattar, M.A.; Alataway, A.; Hassan, S.M. Effect of Pterocladia capillacea seaweed extracts on growth parameters and biochemical constituents of Jew's Mallow. Agronomy 2020, 10, 420. [CrossRef]

10. Ashour, M.; Hassan, S.M.; Elshobary, M.E.; Ammar, G.A.; Gaber, A.; Alsanie, W.F.; Mansour, A.T.; El-Shenody, R. Impact of commercial seaweed liquid extract $\left(\mathrm{TAM}^{\circledR}\right)$ biostimulant and its bioactive molecules on Growth and Antioxidant Activities of Hot Pepper (Capsicum annuum). Plants 2021, 10, 1045. [CrossRef] [PubMed]

11. Castellanos-Barriga, L.G.; Santacruz-Ruvalcaba, F.; Hernández-Carmona, G.; Ramírez-Briones, E.; Hernández-Herrera, R.M. Effect of seaweed liquid extracts from Ulva lactuca on seedling growth of mung bean (Vigna radiata). J. Appl. Phycol. 2017, 29, 2479-2488. [CrossRef]

12. Hassan, S.M.; Ashour, M.; Sakai, N.; Zhang, L.; Hassanien, H.A.; Gaber, A.; Ammar, G. Impact of seaweed liquid extract biostimulant on growth, yield, and chemical composition of cucumber (Cucumis sativus). Agriculture 2021, 11, 320. [CrossRef]

13. Hassan, S.M.; Ashour, M.; Soliman, A.A.; Hassanien, H.A.; Alsanie, W.F.; Gaber, A.; Elshobary, M.E. The potential of a new commercial seaweed extract in stimulating morpho-agronomic and bioactive properties of Eruca vesicaria (L.) Cav. Sustainability 2021, 13, 4485. [CrossRef]

14. Carillo, P.; Ciarmiello, L.F.; Woodrow, P.; Corrado, G.; Chiaiese, P.; Rouphael, Y. Enhancing sustainability by improving plant salt tolerance through macro-and micro-algal biostimulants. Biology 2020, 9, 253. [CrossRef] [PubMed]

15. Chiaiese, P.; Corrado, G.; Colla, G.; Kyriacou, M.C.; Rouphael, Y. Renewable sources of plant biostimulation: Microalgae as a sustainable means to improve crop performance. Front. Plant Sci. 2018, 9, 1782. [CrossRef] [PubMed]

16. Sharma, R.; Datta, S.; Varghese, E. Effect of Surround $W \mathrm{P}^{\circledR}$, a kaolin-based particle film on sunburn, fruit cracking and postharvest quality of 'Kandhari'pomegranates. Crop Prot. 2018, 114, 18-22. [CrossRef]

17. Du Jardin, P. Plant biostimulants: Definition, concept, main categories and regulation. Sci. Hortic. 2015, 196, 3-14. [CrossRef]

18. Shukla, P.S.; Shotton, K.; Norman, E.; Neily, W.; Critchley, A.T.; Prithiviraj, B. Seaweed extract improve drought tolerance of soybean by regulating stress-response genes. AoB Plants 2018, 10, plx051. [CrossRef]

19. Frioni, T.; VanderWeide, J.; Palliotti, A.; Tombesi, S.; Poni, S.; Sabbatini, P. Foliar vs. soil application of Ascophyllum nodosum extracts to improve grapevine water stress tolerance. Sci. Hortic. 2021, 277, 109807. [CrossRef]

20. Spann, T.M.; Little, H.A. Applications of a commercial extract of the brown seaweed Ascophyllum nodosum increases drought tolerance in container-grown 'Hamlin'sweet orange nursery trees. HortScience 2011, 46, 577-582. [CrossRef]

21. Goñi, O.; Quille, P.; O'Connell, S. Ascophyllum nodosum extract biostimulants and their role in enhancing tolerance to drought stress in tomato plants. Plant Physiol. Biochem. 2018, 126, 63-73. [CrossRef] [PubMed]

22. Mancuso, S.; Briand, X.; Mugnai, S.; Azzarello, E. Marine bioactive substances (IPA Extract) improve foliar ion uptake and water stress tolerance in potted "Vitis vinifera" plants. Adv. Hortic. Sci. 2006, 20, 1000-1006.

23. Tombesi, S.; Frioni, T.; Sabbatini, P.; Poni, S.; Palliotti, A. Ascophyllum nodosum extract improves leaf thermoregulation by reducing stomatal sensitivity to VPD in Vitis vinifera L. J. Appl. Phycol. 2021, 33, 1293-1304. [CrossRef]

24. Irani, H.; ValizadehKaji, B.; Naeini, M.R. Biostimulant-induced drought tolerance in grapevine is associated with physiological and biochemical changes. Chem. Biol. Technol. Agric. 2021, 8, 5. [CrossRef]

25. Spann, T.M.; Little, H.A. Effect of Stimplex ${ }^{\circledR}$ crop biostimulant on drought tolerance of 'Hamlin'sweet orange. In Proceedings of the 123rd Annual Meeting of the Florida State Horticultural Society, Crystal River, FL, USA, 6-8 June 2010; pp. 100-104.

26. Kapur, B.; Sarıdaş, M.A.; Çeliktopuz, E.; Kafkas, E.; Karg1, S.P. Health and taste related compounds in strawberries under various irrigation regimes and bio-stimulant application. Food Chem. 2018, 263, 67-73. [CrossRef] [PubMed]

27. Mugnai, S.; Azzarello, E.; Pandolfi, C.; Salamagne, S.; Briand, X.; Mancuso, S. Enhancement of ammonium and potassium root influxes by the application of marine bioactive substances positively affects Vitis vinifera plant growth. J. Appl. Phycol. 2008, 20, 177-182. [CrossRef]

28. Spinelli, F.; Fiori, G.; Noferini, M.; Sprocatti, M.; Costa, G. A novel type of seaweed extract as a natural alternative to the use of iron chelates in strawberry production. Sci. Hortic. 2010, 125, 263-269. [CrossRef]

29. Carrasco-Gil, S.; Hernandez-Apaolaza, L.; Lucena, J.J. Effect of several commercial seaweed extracts in the mitigation of iron chlorosis of tomato plants (Solanum lycopersicum L.). Plant Growth Regul. 2018, 86, 401-411. [CrossRef]

30. Saa, S.; Rio, O.-D.; Castro, S.; Brown, P.H. Foliar application of microbial and plant based biostimulants increases growth and potassium uptake in almond (Prunus dulcis [Mill.] DA Webb). Front. Plant Sci. 2015, 6, 87. [CrossRef] [PubMed]

31. Al-Shatri, A.; Pakyürek, M.; Yavic, A. Effect of seaweed application on nutrient uptake of strawberry cv. Albion grown under the environmental conditions of northern iraq. Appl. Ecol. Environ. Res. 2020, 18, 1267-1279. [CrossRef]

32. Spinelli, F.; Fiori, G.; Noferini, M.; Sprocatti, M.; Costa, G. Perspectives on the use of a seaweed extract to moderate the negative effects of alternate bearing in apple trees. J. Hortic. Sci. Biotechnol. 2009, 84, 131-137. [CrossRef]

33. Frioni, T.; Sabbatini, P.; Tombesi, S.; Norrie, J.; Poni, S.; Gatti, M.; Palliotti, A. Effects of a biostimulant derived from the brown seaweed Ascophyllum nodosum on ripening dynamics and fruit quality of grapevines. Sci. Hortic. 2018, 232, 97-106. [CrossRef] 
34. Frioni, T.; Tombesi, S.; Quaglia, M.; Calderini, O.; Moretti, C.; Poni, S.; Gatti, M.; Moncalvo, A.; Sabbatini, P.; Berrìos, J.G. Metabolic and transcriptional changes associated with the use of Ascophyllum nodosum extracts as tools to improve the quality of wine grapes (Vitis vinifera cv. Sangiovese) and their tolerance to biotic stress. J. Sci. Food Agric. 2019, 99, 6350-6363. [CrossRef]

35. Soppelsa, S.; Kelderer, M.; Casera, C.; Bassi, M.; Robatscher, P.; Andreotti, C. Use of biostimulants for organic apple production: Effects on tree growth, yield, and fruit quality at harvest and during storage. Front. Plant Sci. 2018, 9, 1342. [CrossRef] [PubMed]

36. Weber, N.; Schmitzer, V.; Jakopic, J.; Stampar, F. First fruit in season: Seaweed extract and silicon advance organic strawberry (Fragaria $\times$ ananassa Duch.) fruit formation and yield. Sci. Hortic. 2018, 242, 103-109. [CrossRef]

37. Gutiérrez-Gamboa, G.; Pérez-Donoso, A.G.; Pou-Mir, A.; Acevedo-Opazo, C.; Valdés-Góme, H. Hydric behaviour and gas exchange in different grapevine varieties (Vitis vinifera L.) from the Maule Valley (Chile). S. Afr. J. Enol. 2019, 40, 11. [CrossRef]

38. Gutiérrez-Gamboa, G.; Garde-Cerdán, T.; Martínez-Lapuente, L.; Costa, B.S.d.; Rubio-Bretón, P.; Pérez-Álvarez, E.P. Phenolic composition of Tempranillo Blanco (Vitis vinifera L.) grapes and wines after biostimulation via a foliar seaweed application. J. Sci. Food Agric. 2020, 100, 825-835. [CrossRef]

39. Gutiérrez-Gamboa, G.; Garde-Cerdán, T.; Rubio-Bretón, P.; Pérez-Álvarez, E.P. Study of must and wine amino acids composition after seaweed applications to Tempranillo blanco grapevines. Food Chem. 2020, 308, 125605. [CrossRef]

40. Soppelsa, S.; Kelderer, M.; Casera, C.; Bassi, M.; Robatscher, P.; Matteazzi, A.; Andreotti, C. Foliar applications of biostimulants promote growth, yield and fruit quality of strawberry plants grown under nutrient limitation. Agronomy 2019, 9, 483. [CrossRef]

41. Bradshaw, T.; Berkett, L.; Griffith, M.; Kingsley-Richards, S.; Darby, H.; Parsons, R.; Moran, R.; Garcia, M. Assessment of kelp extract biostimulants on disease incidence and damage in a certified organic apple orchard. Acta Hortic. 2013, 1001, $265-271$. [CrossRef]

42. Graziani, G.; Ritieni, A.; Cirillo, A.; Cice, D.; Di Vaio, C. Effects of biostimulants on annurca fruit quality and potential nutraceutical compounds at harvest and during storage. Plants 2020, 9, 775. [CrossRef] [PubMed]

43. Gutiérrez-Gamboa, G.; Garde-Cerdán, T.; Rubio-Bretón, P.; Pérez-Álvarez, E.P. Biostimulation to Tempranillo grapevines (Vitis vinifera L.) through a brown seaweed during two seasons: Effects on grape juice and wine nitrogen compounds. Sci. Hortic. 2020, 264, 109177. [CrossRef]

44. Chouliaras, V.; Tasioula, M.; Chatzissavvidis, C.; Therios, I.; Tsabolatidou, E. The effects of a seaweed extract in addition to nitrogen and boron fertilization on productivity, fruit maturation, leaf nutritional status and oil quality of the olive (Olea europaea L.) cultivar Koroneiki. J. Sci. Food Agric. 2009, 89, 984-988. [CrossRef]

45. Vanrykel, T.; Vercammen, J.; van Daele, G. Cracking of Sweet Cherries: Past Tense? In Proceedings of the V International Cherry Symposium 795, Bursa, Turkey, 6-10 June 2005; pp. 463-468.

46. Zellner, W.; Datnoff, L. Silicon as a biostimulant in agriculture. In Biostimulants for Sustainable Crop Production; Rouphael, Y., du Jardin, P., Brown, P., De Pascale, S., Colla, G., Eds.; Burleigh Dodds Science Publishing Limited: Cambridge, UK, 2020; pp. 149-195.

47. Epstein, E. Silicon. Annu. Rev. Plant Biol. 1999, 50, 641-664. [CrossRef]

48. Ma, J.F.; Yamaji, N. Silicon uptake and accumulation in higher plants. Trends Plant Sci. 2006, 11, 392-397. [CrossRef] [PubMed]

49. Guntzer, F.; Keller, C.; Meunier, J.-D. Benefits of plant silicon for crops: A review. Agron. Sustain. Dev. 2012, 32, 201-213. [CrossRef]

50. Savvas, D.; Ntatsi, G. Biostimulant activity of silicon in horticulture. Sci. Hortic. 2015, 196, 66-81. [CrossRef]

51. Laane, H.-M. The effects of foliar sprays with different silicon compounds. Plants 2018, 7, 45. [CrossRef] [PubMed]

52. Haynes, R.J. A contemporary overview of silicon availability in agricultural soils. J. Plant Nutr. Soil Sci. 2014, 177, 831-844. [CrossRef]

53. Song, A.; Li, P.; Li, Z.; Fan, F.; Nikolic, M.; Liang, Y. The alleviation of zinc toxicity by silicon is related to zinc transport and antioxidative reactions in rice. Plant Soil 2011, 344, 319-333. [CrossRef]

54. Liang, Y.; Chen, Q.; Liu, Q.; Zhang, W.; Ding, R. Exogenous silicon (Si) increases antioxidant enzyme activity and reduces lipid peroxidation in roots of salt-stressed barley (Hordeum vulgareL.). J. Plant Physiol. 2003, 160, 1157-1164. [CrossRef]

55. Shi, Q.; Bao, Z.; Zhu, Z.; He, Y.; Qian, Q.; Yu, J. Silicon-mediated alleviation of Mn toxicity in Cucumis sativus in relation to activities of superoxide dismutase and ascorbate peroxidase. Phytochemistry 2005, 66, 1551-1559. [CrossRef]

56. Ueno, O.; Agarie, S. Silica deposition in cell walls of the stomatal apparatus of rice leaves. Plant Prod. Sci. 2005, 8, 71-73. [CrossRef]

57. Helaly, M.N.; El-Hoseiny, H.; El-Sheery, N.I.; Rastogi, A.; Kalaji, H.M. Regulation and physiological role of silicon in alleviating drought stress of mango. Plant Physiol. Biochem. 2017, 118, 31-44. [CrossRef] [PubMed]

58. Qin, L.; Kang, W.-h.; Qi, Y.-l.; Zhang, Z.-w.; Wang, N. The influence of silicon application on growth and photosynthesis response of salt stressed grapevines (Vitis vinifera L.). Acta Physiol. Plant. 2016, 38, 68. [CrossRef]

59. Yaghubi, K.; Ghaderi, N.; Vafaee, Y.; Javadi, T. Potassium silicate alleviates deleterious effects of salinity on two strawberry cultivars grown under soilless pot culture. Sci. Hortic. 2016, 213, 87-95. [CrossRef]

60. Elsheery, N.I.; Helaly, M.N.; El-Hoseiny, H.M.; Alam-Eldein, S.M. Zinc oxide and silicone nanoparticles to improve the resistance mechanism and annual productivity of salt-stressed mango trees. Agronomy 2020, 10, 558. [CrossRef]

61. Aras, S. Silicon nutrition in alleviating salt stress in apple plant. Acta Sci. Pol. Hortorum Cultus 2020, 19, 3-10. [CrossRef]

62. Peris-Felipo, F.J.; Benavent-Gil, Y.; Hernández-Apaolaza, L. Silicon beneficial effects on yield, fruit quality and shelf-life of strawberries grown in different culture substrates under different iron status. Plant Physiol. Biochem. 2020, 152, 23-31. [CrossRef] [PubMed] 
63. Ouellette, S.; Goyette, M.-H.; Labbé, C.; Laur, J.; Gaudreau, L.; Gosselin, A.; Dorais, M.; Deshmukh, R.K.; Bélanger, R.R. Silicon transporters and effects of silicon amendments in strawberry under high tunnel and field conditions. Front. Plant Sci. 2017, 8, 949. [CrossRef]

64. Gallegos-Cedillo, V.M.; Álvaro, J.E.; Capatos, T.; Hachmann, T.L.; Carrasco, G.; Urrestarazu, M. Effect of pH and silicon in the fertigation solution on vegetative growth of blueberry plants in organic agriculture. HortScience 2018, 53, 1423-1428. [CrossRef]

65. Wójcik, P. Response of 'red delicious' apple trees drip-fertigated with ammonium nitrate to application of silicic acid. Sci. Hortic. 2019, 249, 15-21. [CrossRef]

66. Dann, E.K.; Le, D.P. Effects of silicon amendment on soilborne and fruit diseases of avocado. Plants 2017, 6, 51. [CrossRef] [PubMed]

67. Kaiser, C.; Christensen, J.; Whiting, M.; Azarenko, A.; Long, L. Effects of soluble potassium silicate soil drenching on sweet cherry fruit quality. In Proceedings of the VI International Cherry Symposium, Reñaca, Chile, 15 February 2014; pp. 339-346.

68. Gomes, T.M.; Mazon, L.F.; Panceri, C.P.; Machado, B.D.; Brighenti, A.; Burin, V.M.; Bordignon-Luiz, M.T. Changes in vineyard productive attributes and phytochemical composition of sauvignon blanc grape and wine induced by the application of silicon and calcium. J. Sci. Food Agric. 2020, 100, 1547-1557. [CrossRef]

69. Valentinuzzi, F.; Pii, Y.; Mimmo, T.; Savini, G.; Curzel, S.; Cesco, S. Fertilization strategies as a tool to modify the organoleptic properties of raspberry (Rubus idaeus L.) fruits. Sci. Hortic. 2018, 240, 205-212. [CrossRef]

70. Zhang, M.; Liang, Y.; Chu, G. Applying silicate fertilizer increases both yield and quality of table grape (Vitis vinifera L.) grown on calcareous grey desert soil. Sci. Hortic. 2017, 225, 757-763. [CrossRef]

71. Schaafsma, G. Safety of protein hydrolysates, fractions thereof and bioactive peptides in human nutrition. Eur. J. Clin. Nutr. 2009, 63, 1161-1168. [CrossRef]

72. Colla, G.; Nardi, S.; Cardarelli, M.; Ertani, A.; Lucini, L.; Canaguier, R.; Rouphael, Y. Protein hydrolysates as biostimulants in horticulture. Sci. Hortic. 2015, 196, 28-38. [CrossRef]

73. Colla, G.; Hoagland, L.; Ruzzi, M.; Cardarelli, M.; Bonini, P.; Canaguier, R.; Rouphael, Y. Biostimulant action of protein hydrolysates: Unraveling their effects on plant physiology and microbiome. Front. Plant Sci. 2017, 8, 2202. [CrossRef]

74. Ertani, A.; Pizzeghello, D.; Francioso, O.; Sambo, P.; Sanchez-Cortes, S.; Nardi, S. Capsicum chinensis L. growth and nutraceutical properties are enhanced by biostimulants in a long-term period: Chemical and metabolomic approaches. Front. Plant Sci. 2014, 5, 375. [CrossRef]

75. Mataffo, A.; Scognamiglio, P.; Dente, A.; Strollo, D.; Colla, G.; Rouphael, Y.; Basile, B. Foliar application of an amino acid-enriched urea fertilizer on 'Greco'grapevines at full veraison increases berry yeast-assimilable nitrogen content. Plants 2020, 9, 619. [CrossRef]

76. Visconti, F.; de Paz, J.M.; Bonet, L.; Jordà, M.; Quinones, A.; Intrigliolo, D.S. Effects of a commercial calcium protein hydrolysate on the salt tolerance of Diospyros kaki L. cv.“Rojo Brillante” grafted on Diospyros lotus L. Sci. Hortic. 2015, 185, 129-138. [CrossRef]

77. Marfà, O.; Cáceres, R.; Polo, J.; Ródenas, J. Animal protein hydrolysate as a biostimulant for transplanted strawberry plants subjected to cold stress. In Proceedings of the VI International Strawberry Symposium, Huelva, Spain, 7 March 2008 ; pp. 315-318.

78. Bogunovic, I.; Duralija, B.; Gadze, J.; Kisic, I. Biostimulant usage for preserving strawberries to climate damages. Hortic. Sci. 2015, 42, 132-140. [CrossRef]

79. Boselli, M.; Bahouaoui, M.; Lachhab, N.; Sanzani, S.; Ferrara, G.; Ippolito, A. Protein hydrolysates effects on grapevine (Vitis vinifera L., cv. Corvina) performance and water stress tolerance. Sci. Hortic. 2019, 258, 108784. [CrossRef]

80. Meggio, F.; Trevisan, S.; Manoli, A.; Ruperti, B.; Quaggiotti, S. Systematic Investigation of the Effects of a Novel Protein Hydrolysate on the Growth, Physiological Parameters, Fruit Development and Yield of Grapevine (Vitis Vinifera L., cv Sauvignon Blanc) under Water Stress Conditions. Agronomy 2020, 10, 1785. [CrossRef]

81. Bavaresco, L.; Lucini, L.; Squeri, C.; Zamboni, M.; Frioni, T. Protein hydrolysates modulate leaf proteome and metabolome in water-stressed grapevines. Sci. Hortic. 2020, 270, 109413. [CrossRef]

82. Parrado, J.; Escudero-Gilete, M.L.; Friaza, V.; García-Martínez, A.; González-Miret, M.L.; Bautista, J.D.; Heredia, F.J. Enzymatic vegetable extract with bio-active components: Influence of fertiliser on the colour and anthocyanins of red grapes. J. Sci. Food Agric. 2007, 87, 2310-2318. [CrossRef]

83. Garde-Cerdán, T.; López, R.; Portu, J.; González-Arenzana, L.; López-Alfaro, I.; Santamaría, P. Study of the effects of proline, phenylalanine, and urea foliar application to Tempranillo vineyards on grape amino acid content. Comparison with commercial nitrogen fertilisers. Food Chem. 2014, 163, 136-141. [CrossRef] [PubMed]

84. Garde-Cerdán, T.; Portu, J.; López, R.; Santamaría, P. Effect of foliar applications of proline, phenylalanine, urea, and commercial nitrogen fertilizers on stilbene concentrations in Tempranillo musts and wines. Am. J. Enol. Vitic. 2015, 66, 542-547. [CrossRef]

85. Garde-Cerdán, T.; Gutiérrez-Gamboa, G.; López, R.; Rubio-Bretón, P.; Pérez-Álvarez, E. Influence of foliar application of phenylalanine and urea at two doses to vineyards on grape volatile composition and amino acids content. Vitis 2018, 57, 137-141.

86. Cheng, X.; Wang, X.; Zhang, A.; Wang, P.; Chen, Q.; Ma, T.; Li, W.; Liang, Y.; Sun, X.; Fang, Y. Foliar phenylalanine application promoted antioxidant activities in Cabernet Sauvignon by regulating phenolic biosynthesis. J. Agric. Food Chem. 2020, 68, 15390-15402. [CrossRef]

87. Portu, J.; López-Alfaro, I.; Gómez-Alonso, S.; López, R.; Garde-Cerdán, T. Changes on grape phenolic composition induced by grapevine foliar applications of phenylalanine and urea. Food Chem. 2015, 180, 171-180. [CrossRef] 
88. Portu, J.; González-Arenzana, L.; Hermosín-Gutiérrez, I.; Santamaría, P.; Garde-Cerdán, T. Phenylalanine and urea foliar applications to grapevine: Effect on wine phenolic content. Food Chem. 2015, 180, 55-63. [CrossRef] [PubMed]

89. Mosa, W.F.; Ali, H.M.; Abdelsalam, N.R. The utilization of tryptophan and glycine amino acids as safe alternatives to chemical fertilizers in apple orchards. Environ. Sci. Pollut. Res. 2021, 28, 1983-1991. [CrossRef]

90. Basile, B.; Rouphael, Y.; Colla, G.; Soppelsa, S.; Andreotti, C. Appraisal of emerging crop management opportunities in fruit trees, grapevines and berry crops facilitated by the application of biostimulants. Sci. Hortic. 2020, 267, 109330. [CrossRef]

91. Canellas, L.P.; Olivares, F.L.; Aguiar, N.O.; Jones, D.L.; Nebbioso, A.; Mazzei, P.; Piccolo, A. Humic and fulvic acids as biostimulants in horticulture. Sci. Hortic. 2015, 196, 15-27. [CrossRef]

92. Piccolo, A. The supramolecular structure of humic substances: A novel understanding of humus chemistry and implications in soil science. Soil Sci. 2002, 166, 810-832. [CrossRef]

93. Rose, M.T.; Patti, A.F.; Little, K.R.; Brown, A.L.; Jackson, W.R.; Cavagnaro, T.R. A meta-analysis and review of plant-growth response to humic substances: Practical implications for agriculture. Adv. Agron. 2014, 124, 37-89.

94. Aghaeifard, F.; Babalar, M.; Fallahi, E.; Ahmadi, A. Influence of humic acid and salicylic acid on yield, fruit quality, and leaf mineral elements of strawberry (Fragaria $\times$ Ananassa duch.) cv. Camarosa. J. Plant Nutr. 2016, 39, 1821-1829. [CrossRef]

95. El-Razek, E.; Abd-Allah, A.; Saleh, M. Yield and fruit quality of Florida Prince peach trees as affected by foliar and soil applications of humic acid. J. Appl. Sci. Res. 2012, 8, 5724-5729.

96. El-Hoseiny, H.M.; Helaly, M.N.; Elsheery, N.I.; Alam-Eldein, S.M. Humic Acid and Boron to Minimize the Incidence of Alternate Bearing and Improve the Productivity and Fruit Quality of Mango Trees. HortScience 2020, 55, 1026-1037. [CrossRef]

97. Kamal, H.M.; Elisa, M.A.; Mohammed, A.A. Effect of some mineral compounds on yield and fruit quality of pomegranate. Biosci. Res. 2017, 14, 1197-1203.

98. Popescu, G.C.; Popescu, M. Yield, berry quality and physiological response of grapevine to foliar humic acid application. Bragantia 2018, 77, 273-282. [CrossRef]

99. Tarantino, A.; Lops, F.; Disciglio, G.; Lopriore, G. Effects of plant biostimulants on fruit set, growth, yield and fruit quality attributes of 'Orange rubis ${ }^{\circledR \prime}$ apricot (Prunus armeniaca L.) cultivar in two consecutive years. Sci. Hortic. 2018, 239, 26-34. [CrossRef] 